\title{
Cell death signaling and anticancer therapy
}

\author{
Lorenzo Galluzzi ${ }^{1,2,3}$, Ilio Vitale ${ }^{1,2,3}$, Erika Vacchelli, ${ }^{1,2,3}$ and Guido Kroemer ${ }^{1,4,5,6,7 *}$ \\ 1 INSERM U848, Villejuif, France \\ 2 Institut Gustave Roussy, Villejuif, France \\ 3 Université Paris-Sud XI, Villejuif, France \\ ${ }^{4}$ Metabolomics Platform, Institut Gustave Roussy, Villejuif, France \\ ${ }^{5}$ Centre de Recherche des Cordoliers, Paris, France \\ ${ }^{6}$ Pôle de Biologie, Hôpital Européen Georges Pompidou, Paris, France \\ 7 Université Paris Descartes, Paris, France
}

\section{Edited by:}

Eric Solary, University Paris-Sud,

France

\section{Reviewed by:}

Matthias P. Wymann, University of

Basel, Switzerland

Simone Fulda, Goethe-University

Frankfurt, Germany

*Correspondence:

Guido Kroemer, INSERM, U848, Institut Gustave Roussy, Pavillon de Recherche 1, 39 rue Camille Desmoulins, F-94805 Villejuif, France. e-mail:kroemer@orange.fr
For a long time, it was commonly believed that efficient anticancer regimens would either trigger the apoptotic demise of tumor cells or induce a permanent arrest in the $G_{1}$ phase of the cell cycle, i.e., senescence. The recent discovery that necrosis can occur in a regulated fashion and the increasingly more precise characterization of the underlying molecular mechanisms have raised great interest, as non-apoptotic pathways might be instrumental to circumvent the resistance of cancer cells to conventional, pro-apoptotic therapeutic regimens. Moreover, it has been shown that some anticancer regimens engage lethal signaling cascades that can ignite multiple oncosuppressive mechanisms, including apoptosis, necrosis, and senescence. Among these signaling pathways is mitotic catastrophe, whose role as a bona fide cell death mechanism has recently been reconsidered. Thus, anticancer regimens get ever more sophisticated, and often distinct strategies are combined to maximize efficacy and minimize side effects. In this review, we will discuss the importance of apoptosis, necrosis, and mitotic catastrophe in the response of tumor cells to the most common clinically employed and experimental anticancer agents.

Keywords: caspases, lysosomal membrane permeabilization, mitochondrial membrane permeabilization, necrosome, oncosis, phosphatidylserine, RIP1, reactive oxygen species

\section{INTRODUCTION}

For a long time, cell death was considered as a mere "consequence" of cellular life and neglected. Then, starting in the mid-nineteenth century, the demise of cells begun to attract the attention of some biologists, who compiled the first morphological descriptions of cell death. Nevertheless, the notion that cell death can occur in a programmed fashion was not explicitly formulated until as late as 1964, thanks to the seminal work of Richard Lockshin (Lockshin and Williams, 1964). A few years later, John Kerr, Alastair Currie, and Sir Andrew Wyllie, who were studying ischemic injury in the rat liver, described for the first time a form of mammalian cell death that manifests with peculiar morphological features and named it "apoptosis," a term of Greek derivation that translates the "dropping off" of petals or leaves from plants or trees (Kerr, 1965; Kerr et al., 1972). As suggested by its stereotyped nature, apoptosis constitutes a genetically regulated cell death subroutine, a concept that was consolidated in 1980-1990 thanks to the work of Robert Horvitz in Caenorhabditis elegans (Lettre and Hengartner, 2006). Along with the discovery of apoptosis, attempts were made to classify cell death modes based on morphological features. One of such classifications was proposed by Schweichel and Merker in 1973, who exposed rat embryos to toxicants and observed "type I cell death" associated with heterophagy, "type II cell death" associated with autophagy and "type III cell death," which was not associated with any type of digestion (Schweichel and Merker, 1973). Today, type I and type III cell death would be referred to as apoptosis and necrosis, respectively, whereas the existence of bona fide "autophagic cell death" remains a matter of controversy, as in most instances the inhibition of autophagy accelerates, rather than inhibits, cell death (Kroemer and Levine, 2008).

Following the discovery of the signaling pathways that initiate the cellular demise, of the biochemical mechanisms that execute it, and of its consequences at the organismal level, several additional criteria have been used to classify cell death. For instance, at a biochemical level, cell death sometimes, but not always, requires the activation of a specific class of cysteine proteases, namely caspases, leading to the discrimination between caspase-dependent and caspase-independent cell death. From an immunological standpoint, immunogenic cell death (ICD) has been opposed to cell death that is unable to activate the immune system (silent), or even actively represses it (tolerogenic). Finally, functional aspects have been used to discriminate between accidental and programmed cell death (PCD), or between physiological and pathological cell death (Galluzzi et al., 2007).

Along with an ever more precise mechanistic characterization of the cellular demise, in the last decade several neologisms have been coined to indicate presumably novel cell death subroutines that exhibit peculiar morphological, biochemical or functional features (Kroemer et al., 2009). The terms "anoikis," "paraptosis," "pyroptosis," and "pyronecrosis" are a few examples that exemplify this tendency. However, in most cases, these catabolic pathways do not constitute bona fide cell death mechanisms, but rather signaling cascades that engage the apoptotic or necrotic 
machinery (Kepp et al., 2010). Similarly, it seems that "mitotic catastrophe," which in the past has been defined as a cell death instance occurring during or shortly after an aberrant mitosis (Vakifahmetoglu et al., 2008), cannot be considered as a cell death subroutine on its own but rather as an oncosuppressive mechanism that can trigger apoptosis, necrosis, or senescence. Importantly, whereas necrosis has been regarded for a long time as a purely accidental cell death mode, it has recently been shown that it can also occur in a regulated fashion (Vandenabeele et al., 2010).

Before this revolutionary change of perspective occurred, it was believed that efficient anticancer regimens would either kill tumor cells by engaging the apoptotic machinery or permanently arrest them in the $G_{1}$ phase of the cell cycle, thus inducing senescence. Now, it has become evident that there is a wide array of clinically employed and experimental anticancer agents that function by triggering neither "classical" apoptosis nor senescence. Some of these regimens, which are beyond the scope of this review, work by engaging tumor-extrinsic signaling cascades (e.g., they stimulate an antitumor immune response, they inhibit angiogenesis, etc.). Others may induce programmed necrosis or mitotic catastrophe-engaged apoptosis. These notions have generated considerable interest. On one hand, regimens that kill tumor cells by inducing necrosis might be instrumental to circumvent the elevated incidence among tumors of mechanisms for the evasion of apoptotic cell death. On the other hand, it seems that cancer cells (which are often genomically instable) are much more sensitive to the induction of mitotic catastrophe than their normal counterparts, resulting in a more comfortable therapeutic window (Eom et al., 2005).

In this review, we will summarize the main morphological, biochemical, and immunological features of apoptosis, necrosis and mitotic catastrophe and we will discuss the significance of these lethal biochemical cascades in anticancer therapy.

\section{CASPASE-DEPENDENT AND -INDEPENDENT APOPTOSIS}

The morphological features that define the most-studied modality of cell death, apoptosis, include (i) rounding-up of the cell; (ii) retraction of pseudopodes; (iii) reduction of cellular volume; (pyknosis), (iv) chromatin condensation starting from the nuclear periphery (marginalization), followed by overall nuclear shrinkage and breakdown (karyorrhexis); (v) little or no ultrastructural modifications of cytoplasmic organelles; (vi) plasma membrane blebbing (but maintenance of its integrity until the latest stages of the process); (vii) shedding of vacuoles containing cytoplasmic portions and apparently unchanged organelles (known as apoptotic bodies); and (viii) engulfment of apoptotic bodies by resident phagocytes (in vivo) (Galluzzi et al., 2007). When the phagocytic system is absent (e.g., in cell cultures) or inefficient, apoptotic bodies progressively break down and their content spills into the extracellular milieu (secondary necrosis).

According to accepted models, two distinct routes to apoptosis exist, which are ignited by extracellular and intracellular stress signals, respectively. "Extrinsic apoptosis" is predominantly mediated by so-called death receptors (e.g., CD95/FAS), which deliver a lethal signal upon ligand binding, resulting in the intracellular activation of initiator caspase- 8 and executioner caspase-3 and -6 (Wajant, 2002). On the other hand, "intrinsic apoptosis" responds to a wide array of intracellular stress conditions (e.g., DNA damage, oxidative damage) and is controlled by mitochondria, whose permeabilization constitutes a point-of-no-return in the signaling pathway that leads to the activation of the caspase-9-caspase- 3 cascade as well as of multiple caspase-independent cell death effectors (e.g., apoptosisinducing factor, AIF; endonuclease G) (Kroemer et al., 2007). Thus, several biochemical markers have been associated with the execution of apoptotic cell death including: (i) the massive activation of caspases, in particular caspase-3, -6, -8, and -9; (ii) mitochondrial membrane permeabilization and (iii) the internucleosomal cleavage of DNA (Kroemer et al., 2007; Table 1).

However, none of the morphological features and processes that have been linked to apoptosis can be used alone as a bona fide indicator of this cell death subroutine (Kroemer et al., 2009), for several reasons. First, taken singularly, some of these morphological traits can manifest (and most of these biochemical events can occur) during non-apoptotic instances of cell death (Vandenabeele et al., 2010). For instance, MMP reportedly takes place during apoptosis and programmed necrosis (Kroemer et al., 2007; Vandenabeele et al., 2010). Second, not all of these (morphological and functional) characteristics manifest in all instances of apoptosis. As a major example, apoptosis can occur independently of caspases (Chipuk and Green, 2005). Third, it has recently become evident that most, if not all, the players that mediate PCD also have cell death-unrelated functions (Galluzzi et al., 2008). Thus, the activation of the apoptotic executioner caspase- 3 and MMP have been implicated in the differentiation of hematopoietic cells (Zermati et al., 2001; De Botton et al., 2002). Similarly, the caspase-independent cell death effector AIF, which mediates large scale DNA degradation once released from mitochondria (Joza et al., 2001; Kroemer et al., 2007), regulates the assembly/ stability of the respiratory complex I from its physiological localization, i.e., within the mitochondrial intermembrane space (Joza et al., 2005).

Apoptotic cells produce several well-known "find-me" (e.g., soluble lysophosphatidylcholine, LPC; ATP) (Lauber et al., 2003; Elliott et al., 2009) and "eat-me" (e.g., surface-exposed and oxidized phosphatidylserine) (Martin et al., 1995) signals, which allow them to interact with macrophages and to be recruited into tight-fitting phagosomes through a zipper-like mechanism (Krysko et al., 2006). Often, phagocytic cells that take up apoptotic bodies do not activate inflammatory or immunogenic reactions. Thus, for a long time it was thought that developmental and pathological PCD would occur only via apoptosis, as this would not elicit any kind of immune response, in contrast to the well-known inflammatory potential of necrosis (see below) (Galluzzi et al., 2007; Green et al., 2009). This oversimplified view has been definitively invalidated in 2007, when Obeid et al. (2007) demonstrated that some anticancer agents such as anthracyclins and $\gamma$ irradiation are able to kill cancer cells by apoptosis while rendering them able to stimulate a tumor-specific immune response. Since then, great efforts have been directed to the discovery of the molecular mechanisms underlying ICD and it has turned out that ICD depends on the activation of a multi-module 
Table 1 | Main morphological, biochemical, and inflammatory/immunological features of apoptosis, necrosis, and mitotic catastrophe.

\begin{tabular}{|c|c|c|c|}
\hline & Morphological features & Biochemical features & Inflammatory/immune features \\
\hline \multirow[t]{5}{*}{ Apoptosis } & Rounding-up & Caspase activation & Generation of soluble find-me signals (ATP, LPC) \\
\hline & Pseudopode retraction & MMP/LMP & Uptake via tight-fitting phagosomes \\
\hline & $\begin{array}{l}\text { Chromatin condensation } \\
\text { Karyorrhexis }\end{array}$ & $\begin{array}{l}\text { Release of IMS proteins } \\
\text { PS exposure }\end{array}$ & $\begin{array}{l}\text { In some instances, eliciting an immune } \\
\text { response that depends on CRT exposure }\end{array}$ \\
\hline & Apoptotic bodies & ATP depletion & \\
\hline & Phagocytosis & Activation of calpains/cathepsins & \\
\hline \multirow[t]{9}{*}{ Necrosis } & $\begin{array}{l}\text { Increasingly translucent } \\
\text { cytoplasm }\end{array}$ & $\begin{array}{l}\text { RIP1/RIP3 activation } \\
\text { Increased glutamino- and glycogenolysis }\end{array}$ & $\begin{array}{l}\text { Uptake by macrophages } \\
\text { via micropinocytosis }\end{array}$ \\
\hline & Swollen organelles & ROS overgeneration & Most often, pro-inflammatory \\
\hline & Absent karyorrhexis & Activation of calpains/cathepsins & \\
\hline & Oncosis & cPLA2 activation & \\
\hline & PM breakdown & PARP1 hyperactivation & \\
\hline & & ANT inhibition & \\
\hline & & ATP and NAD + depletion & \\
\hline & & Impaired LIP homeostasis & \\
\hline & & Sometimes, PS exposure & \\
\hline \multirow[t]{3}{*}{ Mitotic catastrophe } & Micronucleation & Activation of caspase-2 & Poorly determined \\
\hline & Multinucleation & Prolonged SAC signaling & Most likely, dependent on the executioner \\
\hline & $\begin{array}{l}\text { Apoptotic and/or necrotic } \\
\text { features }\end{array}$ & $\begin{array}{l}\text { TP53 activation } \\
\text { Aberrant levels of cyclin B1 and } \\
\text { signaling via CDK1 }\end{array}$ & $\begin{array}{l}\text { mechanism engaged (i.e., apoptosis, } \\
\text { necrosis or senescence) }\end{array}$ \\
\hline
\end{tabular}

Abbreviations: ANT, adenine nucleotide translocase; CDK1, cyclin-dependent kinase 1; cPLA2, cytosolic phospholipase A2; CRT, calreticulin; $\triangle \Psi_{m^{\prime}}$ mitochondrial transmembrane potential; IMS, mitochondrial intermembrane space; LIP, labile iron pool; LMP, Iysosomal membrane permeabilization; LPC, Iysophosphatidylcholine MMP, mitochondrial membrane permeabilization; PARP1, poly(ADP-ribose) polymerase 1; PM, plasma membrane; RIP, receptorinteracting protein kinase; ROS, reactive oxygen species; SAC, spindle-assembly checkpoint.

signaling pathway that eventually results in the exposure at the cell surface of the endoplasmic reticulum (ER) chaperones calreticulin (CRT) and ERp57 (Panaretakis et al., 2009). The ecto-CRT/ ERp57 complex acts as an "eat-me" signal and functions by binding to a yet-to-be-identified receptor on the surface of dendritic cells (DCs), stimulating the uptake of tumor antigens by DCs and the DC-mediated cross-priming of tumor-specific T lymphocytes (Obeid et al., 2007; Panaretakis et al., 2009).

Numerous clinically used and experimental anticancer agents trigger apoptosis (Table 2). These range from DNAdamaging agents including cisplatin (Schwerdt et al., 2005), ionizing radiations (Mi et al., 2009), and mitomycin c (Pirnia et al., 2002) to proteasome inhibitors such as bortezomib (Bonvini et al., 2007; Shi et al., 2008), from corticosteroids like prednisone (Casale et al., 2003) to inhibitors of histone deacetylases (HDACs) such as vorinostat (Koyama et al., 2010), from topoisomerase I inhibitors like camptothecin (Sanchez-Alcazar et al., 2003), etoposide (Cosse et al., 2007), and mitoxantrone (Cao et al., 2009) to a large number of monoclonal antibodies including bevacizumab (Wedam et al., 2006), cetuximab (Niu et al., 2010), and trastuzumab (Hudis, 2007), just to mention a few examples.

\section{PROGRAMMED NECROSIS}

Similar to their apoptotic counterparts, necrotic cells exhibit peculiar morphological features, though these have been disregarded for decades, along with the conception of necrosis as a totally uncontrollable and accidental phenomenon (Table 1). Initially, necrotic cells were classified in a negative fashion, i.e., dying cells that neither showed morphological traits of apoptotic nor massive autophagic vacuolization (which was considered a sign of autophagic cell death). Now, it has become evident that cells succumbing to necrosis display (i) an increasingly translucent cytoplasm; (ii) swollen organelles; (iii) little ultrastructural modifications of the nucleus including the dilatation of the nuclear membrane and the condensation of chromatin into circumscribed, asymmetrical patches; and (iv) increased cell volume (oncosis), which culminates in the breakdown of the plasma membrane (Vandenabeele et al., 2010). 
Table 2 | Examples of anticancer agents that operate via apoptosis.

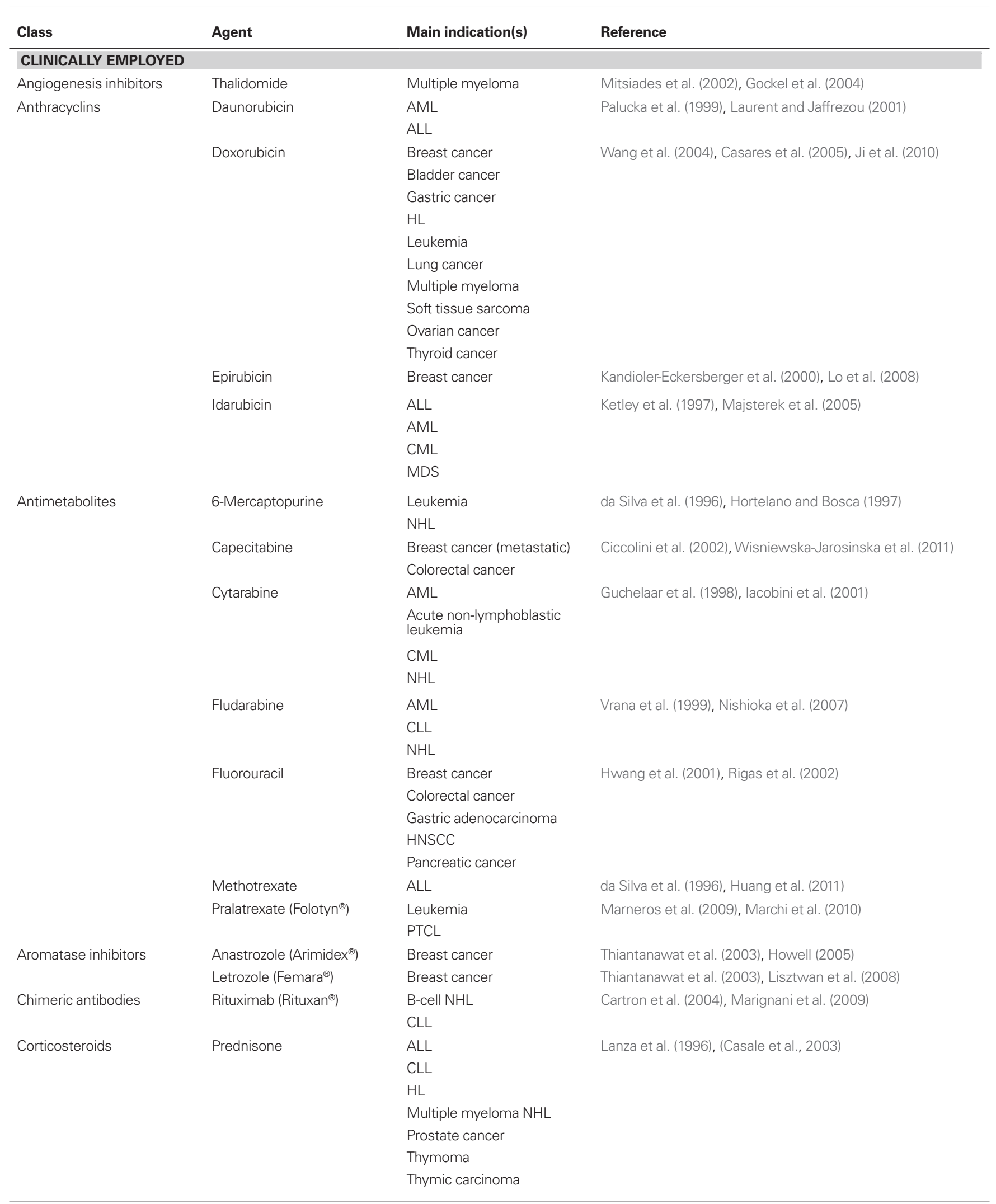




\section{Table 2 | Continued}

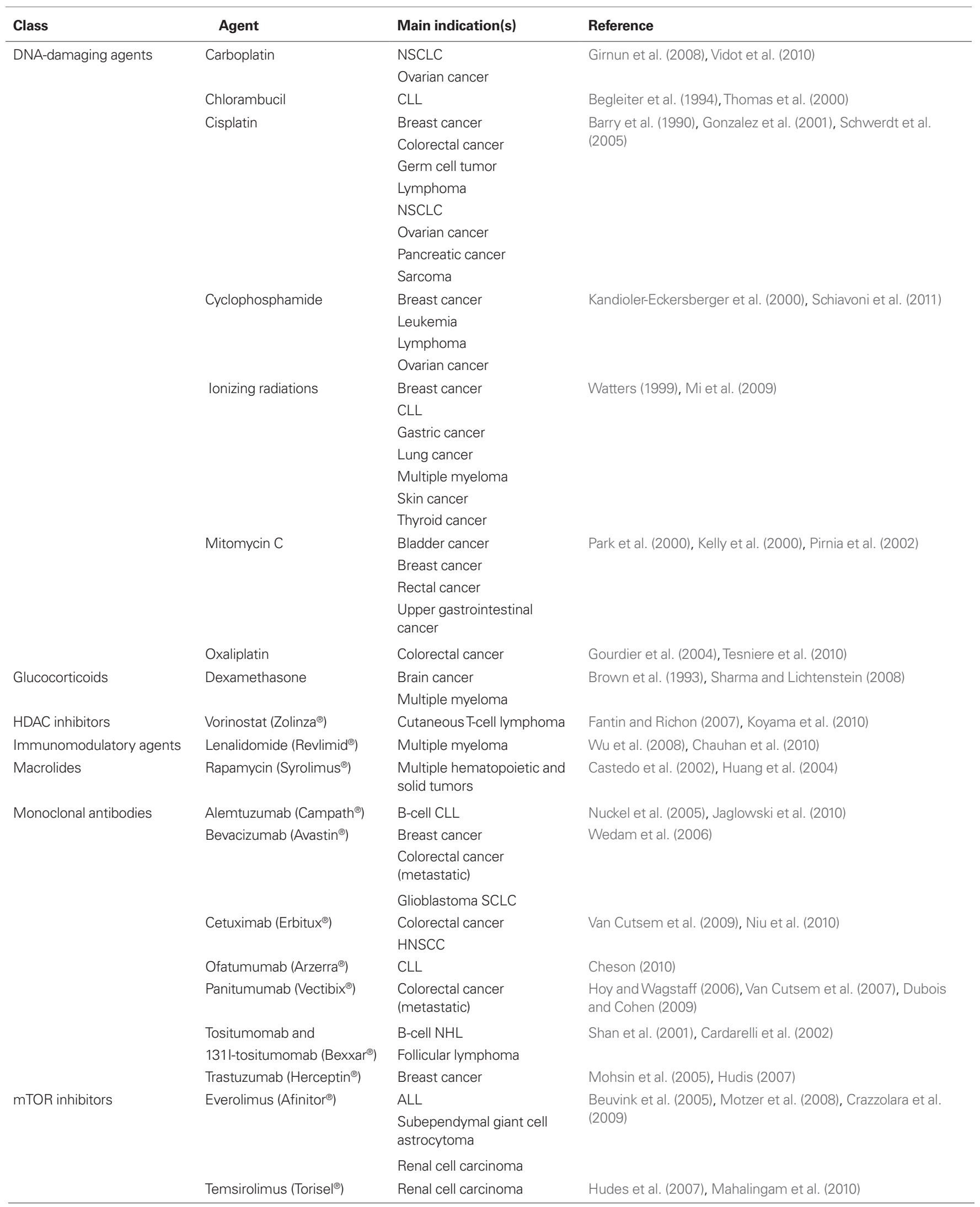


Table 2 | Continued

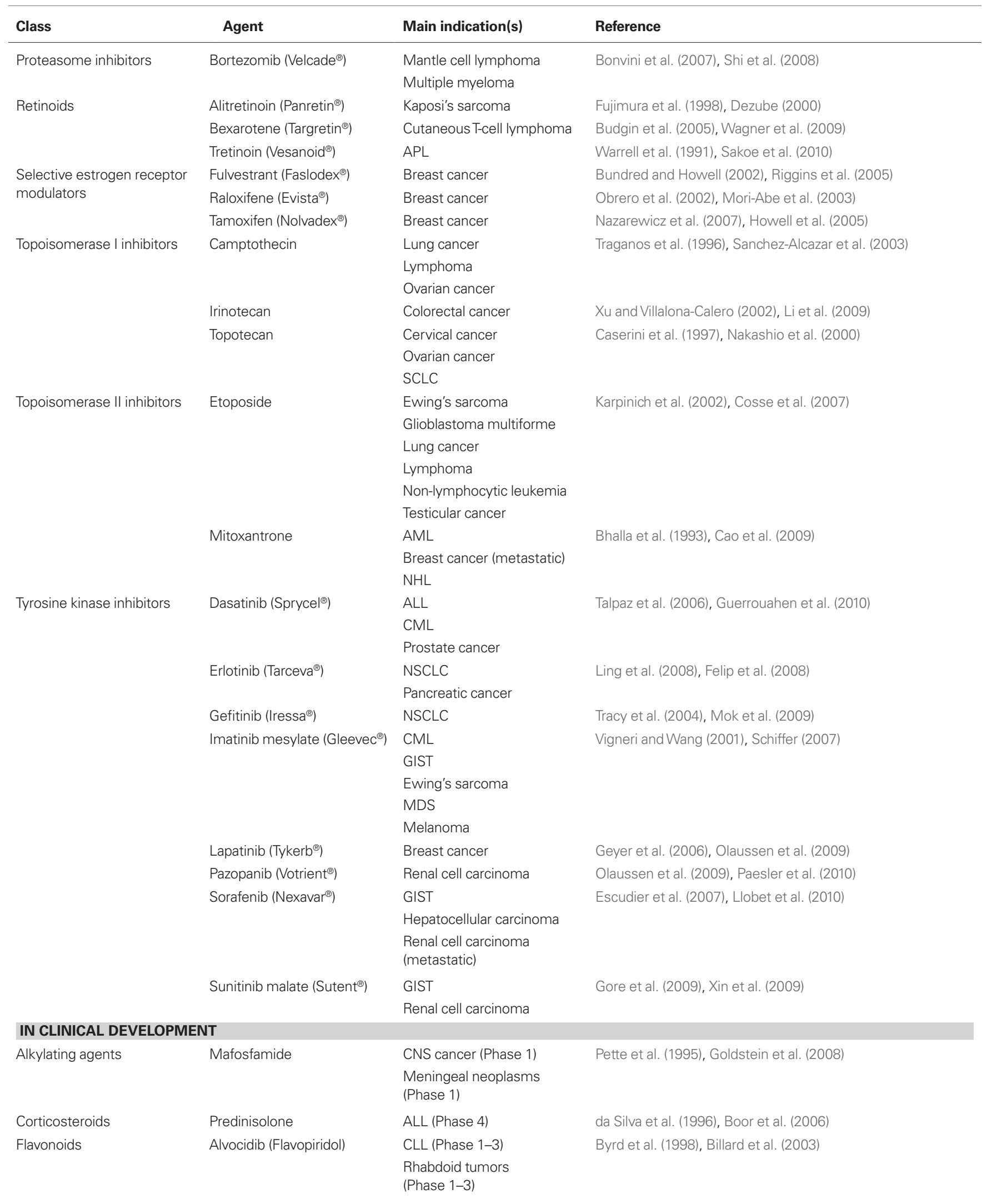


Table 2 | Continued

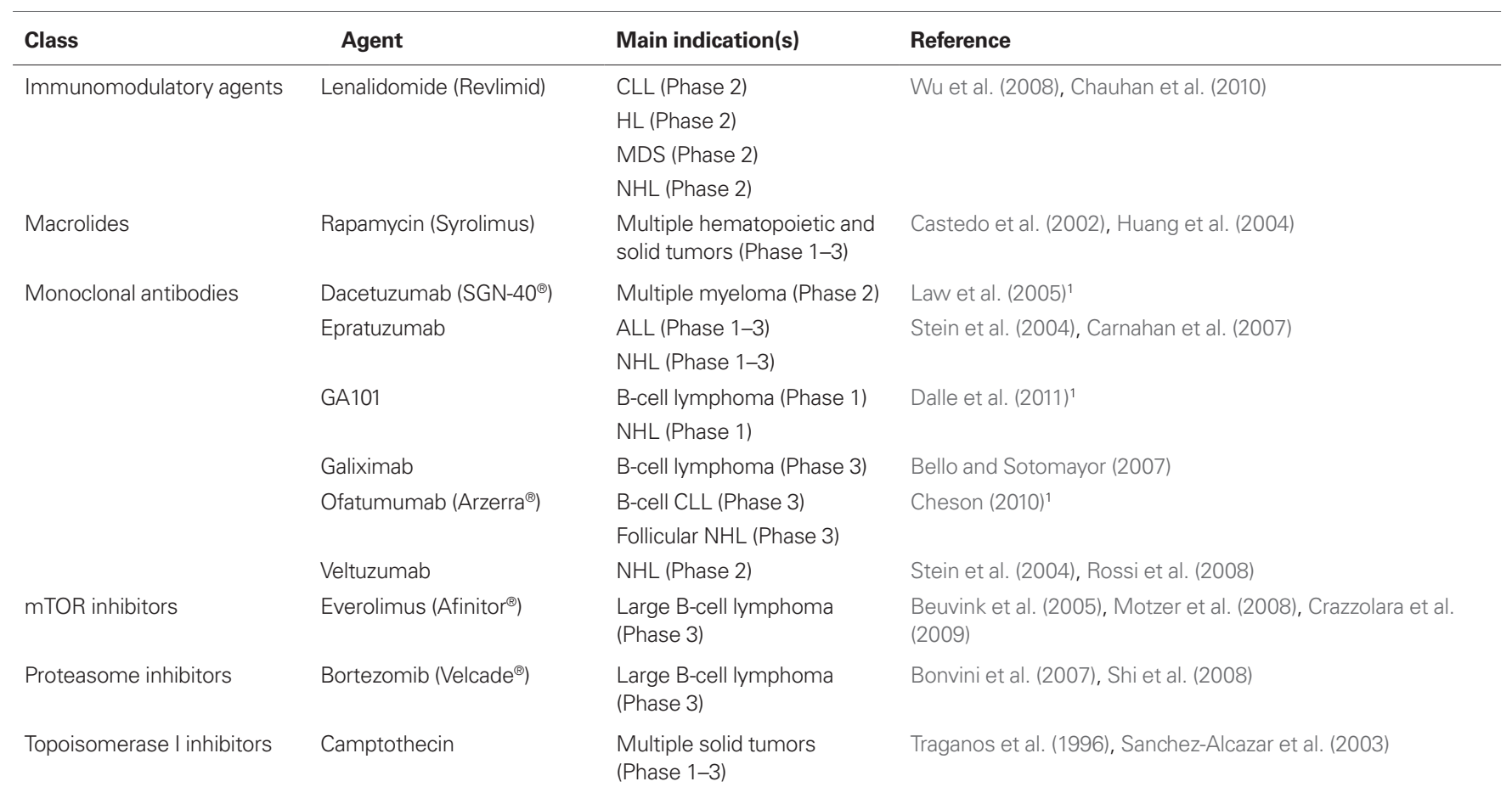

Abbreviations: $A L L$, acute lymphocytic leukemia; $A M L$, acute myeloid leukemia; $A P L$, acute promyelocytic leukemia; $C L L$, chronic lymphocytic leukemia; $C M L$, chronic myeloid leukemia; CNS, central nervous system; GIST, gastrointestinal stromal tumor; HDAC, histone deacetylase; HL, Hodgkin's lymphoma; HNSCC, head and neck squamous cell carcinoma; MDS, myelodysplastic syndrome; mTOR, mammalian target of rapamycin; NHL, non-Hodgkin's lymphoma; NSCLC, non-small cell lung cancer; PTCL, peripheral T-cell lymphoma; SCLC, small cell lung cancer.

'http://www.clinicaltrials.gov

Necrosis does not result in the formation of discrete entities that would be similar to apoptotic bodies. Moreover, the nuclei of necrotic cells do not fragment similar to those of their apoptotic counterparts and have indeed been reported to accumulate in necrotic tissues, in vivo. It should be kept in mind that whereas the signaling pathways and biochemical mechanisms the underlie programmed, accidental, and secondary necrosis are distinct, these phenomena manifest with highly overlapping end-stage morphological features. It is therefore impossible to discriminate among these three processes by relying on single end-point morphological determinations (Galluzzi et al., 2009).

The biochemical processes that ignite and execute programmed necrosis have only recently begun to be unveiled. These include, but are not limited to: (i) the activation of receptor-interacting protein kinases 1 and 3 (RIP1 and RIP3, respectively), which have recently been shown to play a critical role in several instances or programmed necrosis, and in particular in tumor necrosis factor receptor 1 (TNFR1)-elicited necroptosis (Hitomi et al., 2008; Cho et al., 2009; He et al., 2009; Zhang et al., 2009); (ii) a metabolic burst involving the glycogenolytic and glutamynolytic cascades (Goossens et al., 1996; Zhang et al., 2009); (iii) the overgeneration of reactive oxygen species (ROS) by mitochondrial and extra-mitochondrial sources (Goossens et al., 1995, 1999; Kim et al., 2007); (iv) the overproduction of membrane-destabilizing lipids such as sphingosine and ceramide (Thon et al., 2005; Won and Singh, 2006), promoting lysosomal membrane permeabilization (LMP) and the consequent release of toxic hydrolases into the cytosol (Boya and Kroemer, 2008); (v) the generation of cytosolic $\mathrm{Ca}^{2+}$ waves, driving the activation on one hand of $\mathrm{Ca}^{2+}$-dependent non-caspase proteases of the calpain family that favor LMP (Yamashima et al., 2003; Yamashima, 2004; Yamashima and Oikawa, 2009), and, on the other hand, of the cytosolic phospholipase A2 (cPLA2), which catalyzes the first step in the conversion of phospholipids into membranotoxic lipid peroxides (Jayadev et al., 1997; Shinzawa and Tsujimoto, 2003); (vi) the hyperactivation (possibly induced by ROS-triggered DNA damage) of the ATP- and NAD'-dependent nuclear enzyme poly(ADP-ribose) polymerase 1 (PARP1), favoring ATP and $\mathrm{NAD}^{+}$depletion as well as the mitochondrial release of AIF via a calpain-mediated mechanism (Yu et al., 2002; Zong et al., 2004; Moubarak et al., 2007); (vii) the inhibition of the ATP/ADP exchanger of the inner mitochondrial membrane adenine nucleotide translocase (ANT), contributing to ATP depletion (Temkin et al., 2006); and (viii) the generation of a c-JUN N-terminal kinase (JNK)-transduced signal affecting the homeostasis of the redoxactive labile iron pool (LIP), further promoting oxidative stress (Antosiewicz et al., 2007). Most likely this list is not exhaustive and additional processes that are involved in the necrotic disintegration of cells will be discovered in the forthcoming years.

Similar to their apoptotic counterparts, necrotic cells sometimes externalize phosphatidylserine before plasma membrane permeabilization (Krysko et al., 2004), promoting their recognition and uptake by phagocytes (Hirt and Leist, 2003; Brouckaert et al., 
2004). However, full-blown necrosis results in the recruitment of macrophages that internalize necrotic cells via spacious macropinosomes (Krysko et al., 2003), a phenomenon that involves the sorting of fluid-phase macromolecules, as demonstrated by the co-localization of fluid-phase tracers (Krysko et al., 2006). Thus, apoptotic and necrotic cells are handled by the immune system in a radically different fashion. Nevertheless, the phlogistic and immunological consequences of these cell death subroutines cannot be summarized by the old belief that apoptosis always inhibits, while necrosis always stimulates, inflammation and immunity. On one hand, immunogenic instances of apoptosis have been reported (see above). On the other hand, in some cases, necrotic cells can suppress inflammatory reactions (Hirt and Leist, 2003; Brouckaert et al., 2004). These observations suggest that the complexity of the mutual crosstalk between dying cells and the immune system has not been clearly understood yet.

Some clinically employed anticancer regimens (e.g., photodynamic therapy) have been associated with the necrotic regression of tumors (Bown et al., 2002; Lou et al., 2004; Moore et al., 2009), but in most cases it remains to be determined whether such a therapeutic response truly reflects the induction of programmed necrosis. Nevertheless, along with the increasingly more refined understanding of the molecular cascades that underlie regulated necrosis, several compounds are being investigated at pre-clinical and clinical levels for their ability to kill cancer cells by inducing necrosis. Notable examples include DNA alkylating agents, which may trigger cancer cell necrosis via PARP1 hyperactivation (Zong et al., 2004); inhibitors of the cellular inhibitor of apoptosis (cIAP) protein family such as SMAC mimetics, which (at least in vitro) promote necroptosis by facilitating the deubiquitination of RIP1 (Dineen et al., 2010; Vandenabeele et al., 2010; Vanlangenakker et al., 2011); and shikonin, whose promising pro-necrotic activity has not yet been precisely characterized (Han et al., 2007) (Table 3).

\section{MITOTIC CATASTROPHE}

In the last decade, the term "mitotic catastrophe" has been extensively employed to describe a form of cell death affecting higher eukaryotes and has been defined in several fashions, for instance as a case of cell death occurring either during or shortly after aberrant mitosis (Vakifahmetoglu et al., 2008). Nevertheless, the current literature is devoid of a clear-cut definition of this process. The present tendency is to consider mitotic catastrophe as an oncosuppressive signaling cascade that precedes the cellular demise (or senescence) rather than a bona fide cell death executioner mechanism (Vakifahmetoglu et al., 2008; Vitale et al., 2011). Thus, based on functional considerations, mitotic catastrophe can be viewed as a signaling pathway that is activated by perturbations of the mitotic apparatus (including chromosomes and the machinery that ensure their faithful segregation) that are sensed during mitosis and that lead first to (at least some extent of) mitotic arrest and then to cell death of senescence.

In spite of (or even along with) this change of perspective, the interest in mitotic catastrophe as a target for anticancer regimens continues to be high, for at least two reasons. First, a sizeable proportion of cancer cells are tetraploid or aneuploid, which renders them intrinsically more prone to mitotic aberrations and hence particularly sensitive to the induction of mitotic catastrophe
(Vitale et al., 2011). Second, multiple chemotherapeutic agents that are now employed at relatively high doses to trigger cell cycleindependent cell death are very efficient at inducing mitotic catastrophe at lower doses (Eom et al., 2005).

The most prominent morphological features of mitotic catastrophe are (i) micronucleation and (ii) multinucleation. Micronuclei often derive from chromosomes and/or chromosome fragments that have not been distributed evenly between daughter nuclei, whereas two or more nuclei with similar or heterogeneous sizes can be generated upon an aberrant karyokinesis (Vakifahmetoglu et al., 2008). Once mitotic catastrophe proceeds and engages apoptosis, necrosis, or cell senescence, cells acquire at least some of the morphological traits that characterize these processes, resulting in a spectrum of morphotypes that are difficult to classify.

The biochemical events that accompany mitotic catastrophe have not yet been precisely characterized, and there seems to be a high degree of variability in the molecular cascades that are activated in distinct instances of mitotic catastrophe (Gascoigne and Taylor, 2008). Thus, most of the processes that so far have been linked to mitotic catastrophe are required for this lethal cascade in some, but not all, experimental settings. These include (i) the activation of the DNA damage-responsive caspase-2, which reportedly can operate both upstream and downstream MMP (Krumschnabel et al., 2009; Vakifahmetoglu-Norberg and Zhivotovsky, 2010); (ii) the protracted activation of the spindle-assembly checkpoint (SAC), which prevents anaphase (and hence chromosome missegregation) in cells with spindle defects or misattached chromosomes (Musacchio and Salmon, 2007); (iii) the activity of the tumor suppressor protein TP53 (Castedo et al., 2006; Vitale et al., 2007; Huang et al., 2009); and (iv) aberrantly high levels of cyclin B1, leading to prolonged activation of the cyclin-dependent kinase 1 (CDK1) (Harley et al., 2010; Terrano et al., 2010).

Although a role for pro- and anti-apoptotic proteins from the BCL-2 family, for TP53 and for several SAC-related and -unrelated kinases has been demonstrated (Puthalakath et al., 1999, 2001; Castedo et al., 2006; Musacchio and Salmon, 2007; Harley et al., 2010; Terrano et al., 2010), it remains to be clarified how mitotic catastrophe signals to the molecular machineries of apoptosis, necrosis or senescence, and which factors determine the choice among these three oncosuppressive mechanisms. A detailed analysis of the crosstalk between mitotic catastrophe and the inflammatory and immune systems is also missing. With regards to this, it is tempting to speculate that the reaction of the inflammatory/immune system to cells undergoing mitotic catastrophe might be deeply influenced (if not entirely dictated) by the cell fate, be it apoptosis, necrosis, or senescence. Future work will confirm or invalidate this hypothesis.

Irrespective of these incognita, an entire class of clinically employed anticancer agents, i.e., microtubular poisons, operate by inducing mitotic catastrophe. These include taxanes, which disrupt microtubular functions by stabilizing polymerized tubulin; vinca alkaloids, which acts as tubulin depolymerizers; as well as recently developed compounds such as epothilones, which mimic the activity of taxanes yet bind to a distinct binding site on tubulin (Dumontet and Jordan, 2010). In addition, there are several inducers of mitotic catastrophe that are currently being evaluated in pre-clinical and clinical settings, including inhibitors of Aurora kinases (Perez Fidalgo et al., 2009; Lens et al., 2010), of checkpoint 
Table 3 | Examples of anticancer agents that ignite programmed necrosis or mitotic catastrophe.

\begin{tabular}{|c|c|c|c|}
\hline Class & Agent & Main indication(s) & Reference \\
\hline \multicolumn{4}{|c|}{ CLINICALLY EMPLOYED } \\
\hline \multirow[t]{3}{*}{ DNA alkylating agents } & Cyclophosphamide & Breast cancer & Kandioler-Eckersberger et al. (2000), Zong et al. (2004) \\
\hline & & Lymphoma & \\
\hline & & Ovarian cancer & \\
\hline Epothilones & Ixabepilone & Breast cancer & Lee and Swain (2008) \\
\hline HDAC inhibitors & Romidepsin (Istodax $\left.{ }^{\circledast}\right)$ & Cutaneous T cell lymphoma & $\begin{array}{l}\text { Peart et al. (2003), Woo et al. (2009), Whittaker et al. } \\
\text { (2010) }\end{array}$ \\
\hline \multirow[t]{3}{*}{ Photodynamic therapy } & Temoporfin & HNSCC & Bown et al. (2002), Lou et al. (2004), Moore et al. (2009) \\
\hline & & Pancreatic cancer & \\
\hline & & Prostate cancer & \\
\hline \multirow[t]{7}{*}{ Taxanes } & Cabazitaxel & HRPC (metastatic) & Galsky et al. (2010) \\
\hline & & HRPC & \\
\hline & & NSCLC & \\
\hline & Paclitaxel (Abraxane $\left.{ }^{\circledR}\right)$ & Breast cancer & Nyman et al. (2005), Perez (2009), Miele et al. (2009), \\
\hline & $\left(\mathrm{ABI}-007^{\circledR}\right)$ & Kaposi's sarcoma & Dumontet and Jordan (2010) \\
\hline & & NSCLC & \\
\hline & & Ovarian cancer & \\
\hline \multirow[t]{2}{*}{ Vinca alkaloids } & Vinblastine (Velban $\left.{ }^{\circledR}\right)$ & $\begin{array}{l}\text { Multiple hematopoietic and solid } \\
\text { tumors }\end{array}$ & Dumontet and Jordan (2010) \\
\hline & Vincristine (Oncovin $\left.{ }^{\circledR}\right)$ & $\begin{array}{l}\text { Multiple hematopoietic and solid } \\
\text { tumors }\end{array}$ & Dumontet and Jordan (2010) \\
\hline \multicolumn{4}{|c|}{ IN PRECLINICAL/CLINICAL DEVELOPMENT } \\
\hline \multirow[t]{17}{*}{ AURKs inhibitors } & AS703569 & $\begin{array}{l}\text { Multiple hematopoietic and solid } \\
\text { tumors (Phase 1) }\end{array}$ & McLaughlin et al. (2009) ${ }^{1}$ \\
\hline & AT9283 & Leukemia (Phase 1-2) & Cheung et al. (2009)1 \\
\hline & & Multiple myeloma (Phase 2) & \\
\hline & AZD1152 & AML (Phase 1-3) & Wilkinson et al. (2007) $)^{1}$ \\
\hline & & Solid tumors (advanced) (Phase 1) & \\
\hline & MK-0457 (VX-680) & Leukemia (Phase 2) & Harrington et al. (2004), Dar et al. (2010) \\
\hline & & NSCLC (Phase 2) & \\
\hline & & Solid tumors (advanced) (Phase 1) & \\
\hline & MLN8054 & Solid tumors (advanced) (Phase 1) & Hoar et al. (2007), Kitzen et al. (2010) \\
\hline & MLN8237 & AML (advanced) (Phase 2) & Kitzen et al. (2010), Huck et al. (2010) \\
\hline & & MDS (Phase 2) & \\
\hline & & Solid tumors (advanced) (Phase 1) & \\
\hline & PF-03814735 & Solid tumors (advanced) (Phase 1) & Kitzen et al. (2010), Jani et al. (2010) \\
\hline & PHA-739358 & CML (Phase 2) & Carpinelli et al. (2007) ${ }^{1}$ \\
\hline & & Multiple myeloma (Phase 2) & \\
\hline & & HRPC (metastatic) (Phase 2) & \\
\hline & SNS-314 & Solid tumors (advanced) (Phase 1) & Cheung et al. (2009), VanderPorten et al. (2009) \\
\hline clAPs inhibitors & SMAC/DIABLO mimetics & Preclinical development & Foster et al. (2009), He et al. (2009), Awasthi et al. (2011) \\
\hline
\end{tabular}


Table 3 | Continued

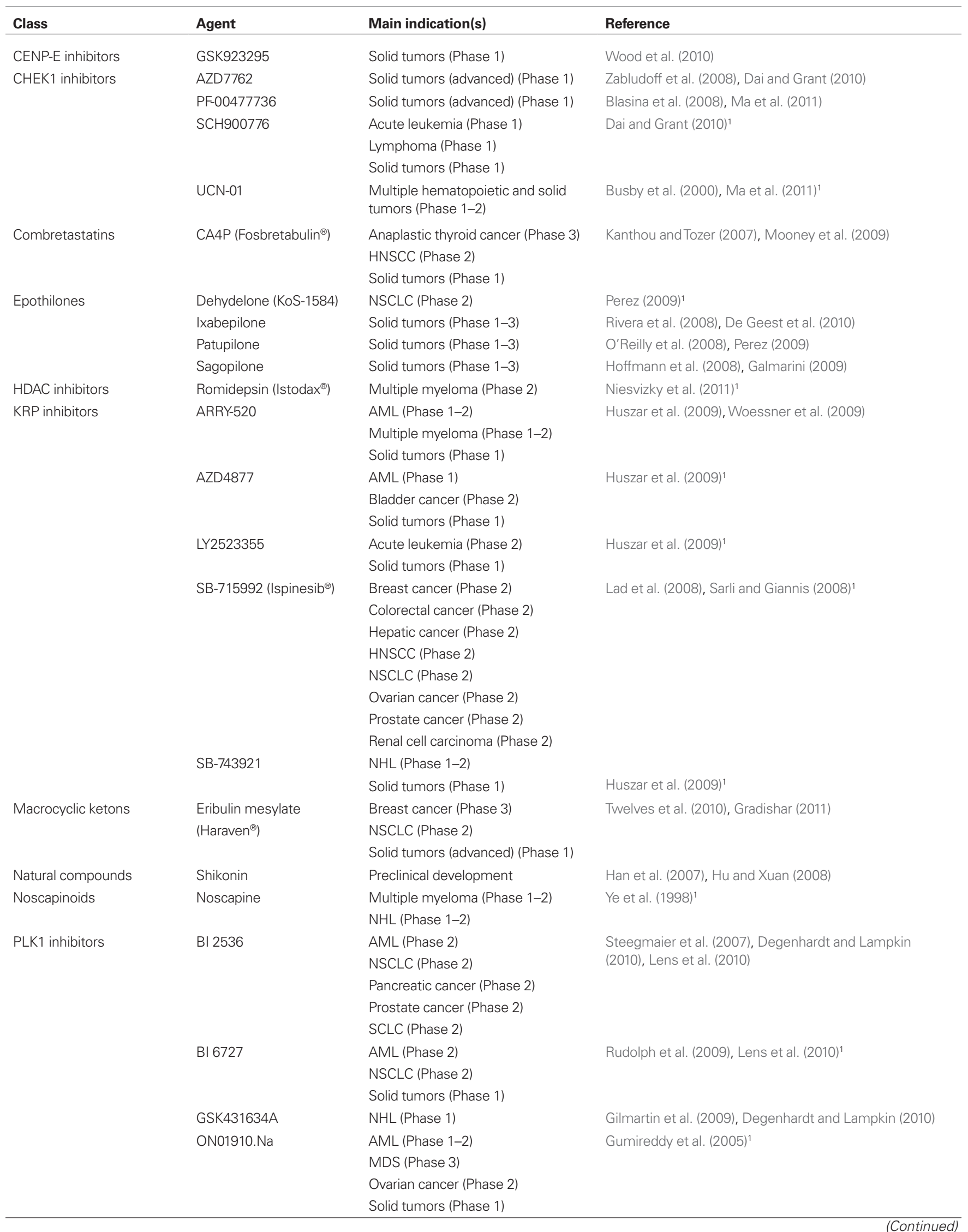


Table 3 | Continued

\begin{tabular}{|c|c|c|c|}
\hline Class & Agent & Main indication(s) & Reference \\
\hline \multirow[t]{9}{*}{ Survivin inhibitors } & LY2181308 & AML (Phase 2) & Carrasco et al. $(2011)^{1}$ \\
\hline & & HRPC (Phase 2) & \\
\hline & Peptide vaccine & Breast cancer (Phase 1) & Ryan et al. (2009) ${ }^{1}$ \\
\hline & & Cervical cancer (Phase 1-2) & \\
\hline & & Pancreatic cancer (Phase 1-2) & \\
\hline & Terameprocol & Leukemia (Phase 1) & Smolewski (2008), Ryan et al. (2009) \\
\hline & & Solid tumors (Phase 1) & \\
\hline & YM155 & HRPC (Phase 2) & Nakahara et al. (2011) ${ }^{1}$ \\
\hline & & Large B cell lymphoma (Phase 2) & \\
\hline \multirow{3}{*}{ Taxanes } & Milataxel (MAC321) & Mesothelioma (Phase 2) & Sampath et al. (2003) ${ }^{1}$ \\
\hline & & Solid tumors (Phase 1) & \\
\hline & Paclitaxel & Various solid tumors (Phase 3) & Dumontet and Jordan (2010) ${ }^{1}$ \\
\hline Topoisomerase I inhibitors & $\beta$-lapachone & $\begin{array}{l}\text { HNSCC (Phase 2) Solid tumors } \\
\text { (Phase 1) }\end{array}$ & Sun et al. $(2006)^{1}$ \\
\hline \multirow[t]{5}{*}{ TTK inhibitors } & AZ3146 & Preclinical development & Hewitt et al. (2010) \\
\hline & Mps1-IN-1/2 & Preclinical development & Kwiatkowski et al. (2010) \\
\hline & NMS-P715 & Preclinical development & Colombo et al. (2010) \\
\hline & Reversine & Preclinical development & Santaguida et al. (2010) \\
\hline & SP600125 & Preclinical development & Schmidt et al. (2005) \\
\hline
\end{tabular}

Abbreviations: ALL, acute lymphocytic leukemia; AML, acute myeloid leukemia; APL, acute promyelocytic leukemia; AURKs, Aurora kinases; CA4P, combretastatin A-4 phosphate; CENP-E, centromere protein E; CHEK1, checkpoint kinase 1; cIAPS, cellular inhibitor of apoptosis proteins; CML, chronic myeloid leukemia; DIABLO, direct IAP-binding protein with low pl; HNSCC, head and neck squamous cell carcinoma; HRPC, hormone-refractory prostate cancer; KRPs, kinesin-related proteins; MDS, myelodysplastic syndrome; NHL, non-Hodgkin's lymphoma; NSCLC, non-small cell lung cancer; PLK1, Polo-like kinase 1; SCLC, small cell lung cancer; SMAC, second mitochondria-derived activator of caspases.

${ }^{1}$ http://www.clinicaltrials.gov

kinase 1 (CHEK1) (Dai and Grant, 2010; Ma et al., 2011), of Pololike kinases (PLKs) (Degenhardt and Lampkin, 2010; Lens et al., 2010), of survivin (Ryan et al., 2009), and of kinesin-related proteins (Huszar et al., 2009), just to mention a few examples (Table 3).

\section{CONCLUDING REMARKS}

So far, two major biochemical cascades that execute cell death have been characterized, i.e., apoptosis and necrosis. While the cytocidal potential of autophagy remains rather controversial, mitotic catastrophe appears to be an oncosuppressive mechanism that operates upstream of the molecular machinery for cell death and cell senescence. As we have discussed above, the vast majority of clinically used and experimental anticancer regimens work by triggering the apoptotic demise of tumor cells, programmed necrosis and mitotic catastrophe being much less employed as therapeutic targets. Nevertheless, since most, if not all, cancer cells exhibit or acquire increased resistance against pro-apoptotic agents, the future of anticancer therapy also relies on the exploitation of non- and pre-apoptotic signaling cascades. The concept of programmed necrosis has gained consensus only a few years ago, along with the idea of circumventing apoptosis resistance by triggering necrosis. Mitotic catastrophe can result in the activation of three distinct oncosuppressive mechanisms, i.e., apoptosis, necrosis and senescence, and cancer cells appear to be intrinsically more sensitive to succumb to this type of death than their normal counterparts. Thus, programmed necrosis and mitotic catastrophe hold great promises for anticancer therapy. It will be really interesting to see how the recent knowledge that has been generated around these oncosuppressive mechanisms will be translated into a clinical reality. 


\section{ACKNOWLEDGMENTS}

Lorenzo Galluzzi is financed by Apo-Sys. Guido Kroemer is supported by the Ligue Nationale contre le Cancer (Equipes labellisée), Agence Nationale pour la Recherche (ANR),

\section{REFERENCES}

Aapro, M. S., Conte, P., Esteban Gonzalez, E., and Trillet-Lenoir, V. (2007). Oral vinorelbine: role in the management of metastatic breast cancer. Drugs 67, 657-667.

Antosiewicz,J.,Ziolkowski,W., Kaczor,J.J., and Herman-Antosiewicz, A. (2007). Tumor necrosis factor-alpha-induced reactive oxygen species formation is mediated by JNK1-dependent ferritin degradation and elevation of labile iron pool. Free Radic. Biol. Med. 43, 265-270.

Awasthi, N., Kirane, A., Schwarz, M. A., Toombs, J. E., Brekken, R. A., and Schwarz, R. E. (2011). Smac mimeticderived augmentation of chemotherapeutic response in experimental pancreatic cancer. BMC Cancer 11,15 . doi: 10.1186/1471-2407-11-15

Barry, M. A., Behnke, C.A., and Eastman, A. (1990). Activation of programmed cell death (apoptosis) by cisplatin, other anticancer drugs, toxins and hyperthermia. Biochem. Pharmacol. 40, 2353-2362.

Begleiter, A., Lee, K., Israels, L. G., Mowat, M. R., and Johnston, J. B. (1994). Chlorambucil induced apoptosis in chronic lymphocytic leukemia (CLL) and its relationship to clinical efficacy. Leukemia 8(Suppl. 1), S103-S106.

Bello, C., and Sotomayor, E. M. (2007). Monoclonal antibodies for B-cell lymphomas: rituximab and beyond. Hematol. Am. Soc. Hematol. Educ. Program. 233-242.

Beuvink, I., Boulay, A., Fumagalli, S., Zilbermann, F., Ruetz, S., O'Reilly, T., Natt, F., Hall, J., Lane, H. A., and Thomas, G. (2005). The mTOR inhibitor RAD001 sensitizes tumor cells to DNA-damaged induced apoptosis through inhibition of $\mathrm{p} 21$ translation. Cell 120, 747-759.

Bhalla, K., Ibrado, A. M., Tourkina, E., Tang, C., Grant, S., Bullock, G., Huang, Y., Ponnathpur, V., and Mahoney, M. E. (1993). High-dose mitoxantrone induces programmed cell death or apoptosis in human myeloid leukemia cells. Blood 82, 3133-3140.

Billard, C., Kern, C., Tang, R.,AjchenbaumCymbalista, F., and Kolb, J. P. (2003). Flavopiridol downregulates the expression of both the inducible NO synthase and p27(kipl) in malignant cells from B-cell chronic lymphocytic leukemia. Leukemia 17, 2435-2443.

Blasina, A., Hallin, J., Chen, E., Arango, M. E., Kraynov, E., Register, J., Grant,
S., Ninkovic, S., Chen, P., Nichols, T., O'Connor, P., and Anderes, K. (2008). Breaching the DNA damage checkpoint via PF-00477736, a novel small-molecule inhibitor of checkpoint kinase 1. Mol. Cancer Ther. 7, 2394-2404.

Bonvini, P., Zorzi, E., Basso, G., and Rosolen, A. (2007). Bortezomibmediated $26 \mathrm{~S}$ proteasome inhibition causes cell-cycle arrest and induces apoptosis in CD-30 + anaplastic large cell lymphoma. Leukemia 21,838-842.

Boor, P. P., Metselaar, H. J., Mancham, S., Tilanus, H. W., Kusters, J. G., and Kwekkeboom, J. (2006). Prednisolone suppresses the function and promotes apoptosis of plasmacytoid dendritic cells. Am. J. Transplant. 6, 2332-2341.

Bown, S. G., Rogowska, A. Z., Whitelaw, D. E., Lees, W. R., Lovat, L. B., Ripley, P., Jones, L., Wyld, P., Gillams, A., and Hatfield, A.W. (2002). Photodynamic therapy for cancer of the pancreas. Gut 50, 549-557.

Boya, P., and Kroemer, G. (2008). Lysosomal membrane permeabilization in cell death. Oncogene 27, 6434-6451.

Brouckaert, G., Kalai, M., Krysko, D. V., Saelens, X., Vercammen, D., Ndlovu, M., Haegeman, G., D’Herde, K., and Vandenabeele, P. (2004). Phagocytosis of necrotic cells by macrophages is phosphatidylserine dependent and does not induce inflammatory cytokine production. Mol. Biol. Cell 15, 1089-1100.

Brown, D. G., Sun, X. M., and Cohen, G. M. (1993). Dexamethasone-induced apoptosis involves cleavage of DNA to large fragments prior to internucleosomal fragmentation. J. Biol. Chem. 268, 3037-3039.

Budgin, J. B., Richardson, S. K., Newton, S. B., Wysocka, M., Zaki, M. H., Benoit, B., and Rook, A. H. (2005). Biological effects of bexarotene in cutaneous T-cell lymphoma. Arch. Dermatol. 141, 315-321.

Bundred, N., and Howell, A. (2002). Fulvestrant (Faslodex): current status in the therapy of breast cancer. Expert Rev. Anticancer Ther. 2, 151-160.

Busby, E. C., Leistritz, D. F., Abraham, R. T., Karnitz, L. M., and Sarkaria, J. N. (2000). The radiosensitizing agent 7-hydroxystaurosporine (UCN-01) inhibits the DNA damage checkpoint kinase hChk1. Cancer Res. 60, 2108-2112.

Byrd, J. C., Shinn, C., Waselenko, J. K., Fuchs, E. J., Lehman, T. A., Nguyen, P.

European Commission (Active p53, Apo-Sys, ChemoRes, ApopTrain), Fondation pour la Recherche Médicale (FRM), Institut National du Cancer (INCa) and Cancéropôle Ile-de-France.

L., Flinn, I. W., Diehl, L. F., Sausville, E., and Grever, M. R. (1998). Flavopiridol induces apoptosis in chronic lymphocytic leukemia cells via activation of caspase- 3 without evidence of bcl-2 modulation or dependence on functional p53. Blood 92, 3804-3816.

Cao, C., Han, Y., Ren, Y., and Wang, Y. (2009). Mitoxantrone-mediated apoptotic B16-F1 cells induce specific anti-tumor immune response. Cell. Mol. Immunol. 6, 469-475.

Cardarelli, P. M., Quinn, M., Buckman, D., Fang, Y., Colcher, D., King, D. J., Bebbington, C., and Yarranton, G. (2002). Binding to CD20 by anti-B1 antibody or $\mathrm{F}\left(\mathrm{ab}^{\prime}\right)(2)$ is sufficient for induction of apoptosis in B-cell lines. Cancer Immunol. Immunother. 51, 15-24.

Carnahan, J., Stein, R., Qu, Z., Hess, K., Cesano, A., Hansen, H. J., and Goldenberg, D. M. (2007). Epratuzumab, a CD22-targeting recombinant humanized antibody with a different mode of action from rituximab. Mol. Immunol. 44, 1331-1341.

Carpinelli, P., Ceruti, R., Giorgini, M. L., Cappella, P., Gianellini, L., Croci, V., Degrassi, A., Texido, G., Rocchetti, M., Vianello, P., Rusconi, L., Storici, P., Zugnoni, P., Arrigoni, C., Soncini, C., Alli, C., Patton, V., Marsiglio, A., Ballinari, D., Pesenti, E., Fancelli, D., and Moll, J. (2007). PHA-739358, a potent inhibitor of Aurora kinases with a selective target inhibition profile relevant to cancer. Mol. Cancer Ther. 6, 3158-3168.

Carrasco, R. A., Stamm, N. B., Marcusson, E., Sandusky, G., Iversen, P., and Patel, B. K. (2011). Antisense inhibition of survivin expression as a cancer therapeutic. Mol. Cancer Ther. 10,221-232.

Cartron, G., Watier, H., Golay, J., and SolalCeligny, P. (2004). From the bench to the bedside: ways to improve rituximab efficacy. Blood 104, 2635-2642.

Casale, F., Addeo, R., D’Angelo, V., Indolfi, P., Poggi, V., Morgera, C., Crisci, S., and Di Tullio, M. T. (2003). Determination of the in vivo effects of prednisone on Bcl-2 family protein expression in childhood acute lymphoblastic leukemia. Int. J. Oncol. 22, 123-128.

Casares, N., Pequignot, M. O., Tesniere, A., Ghiringhelli, F., Roux, S., Chaput, N., Schmitt, E., Hamai, A., HervasStubbs, S., Obeid, M., Coutant, F., Métivier, D., Pichard, E., Aucouturier, P., Pierron, G., Garrido, C., Zitvogel,
L., and Kroemer, G. (2005). Caspasedependent immunogenicity of doxorubicin-induced tumor cell death. $J$. Exp. Med. 202, 1691-1701.

Caserini, C., Pratesi, G., Tortoreto, M., Bedogne, B., Carenini, N., Supino, R. Perego, P., Righetti, S. C., and Zunino, F. (1997). Apoptosis as a determinant of tumor sensitivity to topotecan in human ovarian tumors: preclinical in vitro/in vivo studies. Clin. Cancer Res. 3, 955-961.

Castedo, M., Coquelle, A., Vivet, S., Vitale, I., Kauffmann, A., Dessen, P., Pequignot, M. O., Casares, N., Valent, A., Mouhamad, S., Schmitt, E., Modjtahedi, N., Vainchenker, W. Zitvogel, L., Lazar, V., Garrido, C., and Kroemer, G. (2006). Apoptosis regulation in tetraploid cancer cells. EMBO J. 25, 2584-2595.

Castedo, M., Ferri, K. F., and Kroemer, G. (2002).Mammalian target of rapamycin (mTOR): pro- and anti-apoptotic. Cell Death Differ. 9, 99-100.

Chauhan, D., Singh, A. V., Ciccarelli, B., Richardson, P. G., Palladino, M.A., and Anderson, K. C. (2010). Combination of novel proteasome inhibitor NPI0052 and lenalidomide trigger in vitro and in vivo synergistic cytotoxicity in multiple myeloma. Blood 115, 834-845.

Cheson, B. D. (2010). Ofatumumab, a novel anti-CD20 monoclonal antibody for the treatment of B-cell malignancies. J. Clin. Oncol. 28, 3525-3530.

Cheung, C. H., Coumar, M. S., Hsieh, H. P., and Chang, J. Y. (2009). Aurora kinase inhibitors in preclinical and clinical testing. Expert Opin. Investig. Drugs 18, 379-398.

Chipuk, J. E., and Green, D. R. (2005). Do inducers of apoptosis trigger caspaseindependent cell death? Nat. Rev. Mol. Cell Biol. 6, 268-275.

Cho, Y. S., Challa, S., Moquin, D., Genga, R., Ray, T.D., Guildford, M., and Chan, F. K. (2009). Phosphorylation-driven assembly of the RIP1-RIP3 complex regulates programmed necrosis and virus-induced inflammation. Cell 137, 1112-1123.

Ciccolini, J., Fina, F., Bezulier, K., Giacometti, S., Roussel, M., Evrard, A., Cuq, P., Romain, S., Martin, P. M., and Aubert, C. (2002). Transmission of apoptosis in human colorectal tumor cells exposed to capecitabine, Xeloda, is mediated via Fas. Mol. Cancer Ther. 1, 923-927.

Colombo, R., Caldarelli, M., Mennecozzi, M., Giorgini, M. L., Sola, F., Cappella, 
P., Perrera, C., Depaolini, S. R., Rusconi, L., Cucchi, U., Avanzi, N., Bertrand, J. A., Bossi, R. T., Pesenti, E., Galvani, A., Isacchi, A., Colotta, F., Donati, D., and Moll, J. (2010). Targeting the mitotic checkpoint for cancer therapy with NMS-P715, an inhibitor of MPS1 kinase. Cancer Res. 70, 10255-10264.

Cosse, J. P., Sermeus, A., Vannuvel, K., Ninane, N., Raes, M., and Michiels, C. (2007). Differential effects of hypoxia on etoposide-induced apoptosis according to the cancer cell lines. Mol. Cancer 6, 61.

Crazzolara, R., Cisterne, A., Thien, M., Hewson, J., Baraz, R., Bradstock, K. F., and Bendall, L. J. (2009). Potentiating effects of RAD001 (Everolimus) on vincristine therapy in childhood acute lymphoblastic leukemia. Blood 113, 3297-3306.

da Silva, C. P., de Oliveira, C. R., da Conceicao, M., and de Lima, P. (1996). Apoptosis as a mechanism of cell death induced by different chemotherapeutic drugs in human leukemic T-lymphocytes. Biochem. Pharmacol. 51, 1331-1340.

Dai, Y., and Grant, S. (2010). New insights into checkpoint kinase 1 in the DNA damage response signaling network. Clin. Cancer Res. 16, 376-383.

Dalle, S., Reslan, L., Besseyre de Horts, T., Herveau, S., Herting, F., Plesa, A., Friess, T., Umana, P., Klein, C., and Dumontet, C. (2011). Preclinical studies on the mechanism of action and the anti-lymphoma activity of the novel anti-CD20 antibody GA101. Mol. Cancer Ther. 10, 178-185.

Dancey, J., and Steward, W. P. (1995). The role of vindesine in oncology-recommendations after 10 years' experience. Anticancer Drugs 6, 625-636.

Dar, A. A., Goff, L. W., Majid, S., Berlin, J., and El-Rifai, W. (2010). Aurora kinase inhibitors - rising stars in cancer therapeutics? Mol. Cancer Ther. 9, 268-278.

De Botton, S., Sabri, S., Daugas, E., Zermati, Y., Guidotti, J. E., Hermine, O., Kroemer, G., Vainchenker, W., and Debili, N. (2002). Platelet formation is the consequence of caspase activation within megakaryocytes. Blood 100, 1310-1317.

De Geest, K., Blessing, J. A., Morris, R. T., Yamada, S. D., Monk, B. J., Zweizig, S. L., Matei,D., Muller, C.Y., and Richards, W. E. (2010). Phase II clinical trial of ixabepilone in patients with recurrent or persistent platinum- and taxaneresistant ovarian or primary peritoneal cancer: a gynecologic oncology group study. J. Clin. Oncol. 28, 149-153.

Degenhardt, Y., and Lampkin, T. (2010). Targeting Polo-like kinase in cancer therapy. Clin. Cancer Res. 16, 384-389.
Dezube, B. J. (2000). New therapies for the treatment of AIDS-related Kaposi sarcoma. Curr. Opin. Oncol. 12, 445-449.

Dineen, S. P., Roland, C. L., Greer, R., Carbon, J. G., Toombs, J. E., Gupta, P., Bardeesy, N., Sun, H., Williams, N., Minna, J.D., and Brekken, R.A. (2010). Smac mimetic increases chemotherapy response and improves survival in mice with pancreatic cancer. Cancer Res. 70, 2852-2861.

Dubois, E. A., and Cohen, A. F. (2009). Panitumumab. Br. J. Clin. Pharmacol. $68,482-483$.

Dumontet, C., and Jordan, M. A. (2010). Microtubule-binding agents: a dynamic field of cancer therapeutics. Nat. Rev. Drug Discov. 9, 790-803.

Elliott, M. R., Chekeni, F. B., Trampont, P. C.,Lazarowski,E. R., Kadl,A., Walk,S.F., Park, D., Woodson, R. I., Ostankovich, M., Sharma, P., Lysiak, J. J., Harden, T. K., Leitinger, N., and Ravichandran, K. S. (2009). Nucleotides released by apoptotic cells act as a find-me signal to promote phagocytic clearance. Nature 461, 282-286.

Eom, Y. W., Kim, M. A., Park, S. S., Goo, M. J., Kwon, H. J., Sohn, S., Kim, W. H., Yoon, G., and Choi, K. S. (2005). Two distinct modes of cell death induced by doxorubicin: apoptosis and cell death through mitotic catastrophe accompanied by senescence-like phenotype. Oncogene 24, 4765-4777.

Escudier, B., Eisen, T., Stadler, W. M., Szczylik, C., Oudard, S., Siebels, M., Negrier, S., Chevreau, C., Solska, E., Desai, A. A., Rolland, F., Demkow, T., Hutson, .T. E., Gore, M., Freeman, S., Schwartz, B., Shan, M., Simantov, R., Bukowski, R. M., and TARGET Study Group. (2007). Sorafenib in advanced clear-cell renal-cell carcinoma. $N$. Engl. J. Med. 356, 125-134.

Fantin, V. R., and Richon, V. M. (2007). Mechanisms of resistance to histone deacetylase inhibitors and their therapeutic implications. Clin. Cancer Res. 13, 7237-7242.

Felip, E., Rojo, F., Reck, M., Heller, A., Klughammer, B., Sala, G., Cedres, S., Peralta, S., Maacke, H., Foernzler, D., Parera, M., Möcks, J., Saura, C., Gatzemeier, U., and Baselga, J. (2008). A phase II pharmacodynamic study of erlotinib in patients with advanced non-small cell lung cancer previously treated with platinum-based chemotherapy. Clin. Cancer Res. 14, 3867-3874.

Foster, F. M., Owens, T. W., TanianisHughes, J., Clarke, R. B., Brennan, K., Bundred, N. J., and Streuli, C. H. (2009). Targeting inhibitor of apoptosis proteins in combination with ErbB antagonists in breast cancer. Breast Cancer Res. 11, R41.
Frampton, J. E., and Moen, M. D. (2010). Vinflunine. Drugs 70, 1283-1293.

Fujimura, S., Suzumiya, J., Anzai, K., Ohkubo, K., Hata, T., Yamada, Y., Kamihira, S., Kikuchi, M., and Ono, J. (1998). Retinoic acids induce growth inhibition and apoptosis in adult T-cell leukemia (ATL) cell lines. Leuk. Res. 22, 611-618.

Galluzzi, L., Aaronson, S. A., Abrams, J., Alnemri, E. S., Andrews, D. W., Baehrecke, E. H., Bazan, N. G., Blagosklonny, M. V., Blomgren, K., Borner, C., Bredesen, D. E., Brenner, C., Castedo, M., Cidlowski, J. A. Ciechanover, A., Cohen, G. M., De Laurenzi, V., De Maria, R., Deshmukh, M., Dynlacht, B. D., El-Deiry, W. S., Flavell, R. A., Fulda, S., Garrido, C., Golstein, P., Gougeon, M. L., Green, D. R., Gronemeyer, H., Hajnóczky, G., Hardwick, J. M., Hengartner, M. O., Ichijo, H., Jäättelä, M., Kepp, O., Kimchi, A., Klionsky, D. J., Knight, R. A., Kornbluth, S., Kumar, S., Levine, B., Lipton, S. A., Lugli, E., Madeo, F., Malomi, W., Marine, J. C., Martin, S. J., Medema, J. P., Mehlen, P., Melino, G., Moll, U.M., Morselli, E., Nagata, S., Nicholson, D. W., Nicotera, P., Nuñez, G., Oren, M., Penninger, J., Pervaiz, S., Peter, M. E., Piacentini, M., Prehn, J. H., Puthalakath, H., Rabinovich, G. A., Rizzuto, R., Rodrigues, C. M. Rubinsztein, D. C., Rudel, T., Scorrano L., Simon, H. U., Steller, H., Tschopp, J., Tsujimoto, Y., Vandenabeele, P., Vitale, I., Vousden, K. H., Youle, R. J., Yuan, J., Zhivotovsky, B., and Kroemer, G. (2009). Guidelines for the use and interpretation of assays for monitoring cell death in higher eukaryotes. Cell Death Differ. 16, 1093-1107.

Galluzzi, L., Joza, N., Tasdemir, E., Maiuri, M. C., Hengartner, M., Abrams, J. M., Tavernarakis, N., Penninger, J., Madeo, F., and Kroemer, G. (2008). No death without life: vital functions of apoptotic effectors. Cell Death Differ. 15, 1113-1123.

Galluzzi, L., Maiuri, M. C., Vitale, I., Zischka, H., Castedo, M., Zitvogel, L., and Kroemer, G. (2007). Cell death modalities: classification and pathophysiological implications. Cell Death Differ. 14, 1237-1243.

Galmarini, C. M. (2009). Sagopilone, a microtubule stabilizer for the potential treatment of cancer. Curr. Opin. Investig. Drugs 10, 1359-1371.

Galsky, M. D., Dritselis, A., Kirkpatrick, P., and Oh, W. K. (2010). Cabazitaxel. Nat. Rev. Drug Discov. 9, 677-678.

Gascoigne, K. E., and Taylor, S. S. (2008). Cancer cells display profound intraand interline variation following prolonged exposure to antimitotic drugs. Cancer Cell 14, 111-122.
Geyer, C. E., Forster, J., Lindquist, D., Chan, S., Romieu, C. G., Pienkowski, T., Jagiello-Gruszfeld, A., Crown, J., Chan, A., Kaufman, B., Skarlos, D., Campone, M., Davidson, N., Berger, M., Oliva, C., Rubin, S. D., Stein, S., and Cameron, D. (2006). Lapatinib plus capecitabine for HER2-positive advanced breast cancer. N. Engl. J. Med. 355, 2733-2743.

Gilmartin, A. G., Bleam, M. R., Richter, M. C., Erskine, S. G., Kruger, R. G., Madden, L., Hassler, D. F., Smith, G. K., Gontarek, R. R., Courtney, M. P., Sutton, D., Diamond, M. A., Jackson, J. R., and Laquerre, S. G. (2009). Distinct concentration-dependent effects of the polo-like kinase 1-specific inhibitor GSK461364A, including differential effect on apoptosis. Cancer Res. 69, 6969-6977.

Girnun, G. D., Chen, L., Silvaggi, J., Drapkin, R., Chirieac, L. R., Padera, R. F., Upadhyay, R., Vafai, S. B., Weissleder, R., Mahmood, U., Naseri, E., Buckley, S., Li, D., Force, J., McNamara, K., Demetri, G., Spiegelman, B. M., and Wong, K. K. (2008). Regression of drug-resistant lung cancer by the combination of rosiglitazone and carboplatin. Clin. Cancer Res. 14, 6478-6486.

Gockel, H. R., Lugering, A., Heidemann, J., Schmidt, M., Domschke, W., Kucharzik, T., and Lugering, N. (2004). Thalidomide induces apoptosis in human monocytes by using a cytochrome c-dependent pathway. J. Immunol. 172, 5103-5109.

Goldstein, M., Roos, W. P., and Kaina, B. (2008). Apoptotic death induced by the cyclophosphamide analogue mafosfamide in human lymphoblastoid cells: contribution of DNA replication, transcription inhibition and Chk/p53 signaling. Toxicol. Appl. Pharmacol. 229, 20-32.

Gonzalez, V. M., Fuertes, M. A., Alonso, C., and Perez,J. M. (2001). Is cisplatininduced cell death always produced by apoptosis? Mol. Pharmacol. 59, 657-663.

Goossens, V., Grooten, J., De Vos, K., and Fiers, W. (1995). Direct evidence for tumor necrosis factor-induced mitochondrial reactive oxygen intermediates and their involvement in cytotoxicity. Proc. Natl. Acad. Sci. U.S.A. 92, 8115-8119.

Goossens, V., Grooten, J., and Fiers, W. (1996). The oxidative metabolism of glutamine. A modulator of reactive oxygen intermediate-mediated cytotoxicity of tumor necrosis factor in L929 fibrosarcoma cells. J. Biol. Chem. 271, 192-196

Goossens, V., Stange, G., Moens, K., Pipeleers, D., and Grooten, J. (1999). Regulation of tumor necrosis 
factor-induced, mitochondria- and reactive oxygen species-dependent cell death by the electron flux through the electron transport chain complex I. Antioxid. Redox Signal. 1, 285-295.

Gore, M. E., Szczylik, C., Porta, C., Bracarda, S., Bjarnason, G. A., Oudard, S., Hariharan, S., Lee, S. H., Haanen, J., Castellano, D., Vrdoljak, E., Schöffski, P., Mainwaring, P., Nieto, A., Yuan, J., and Bukowski, R. (2009). Safety and efficacy of sunitinib for metastatic renal-cell carcinoma: an expanded-access trial. Lancet Oncol. 10, 757-763.

Gourdier, I., Crabbe, L., Andreau, K., Pau, B., and Kroemer, G. (2004). Oxaliplatin-induced mitochondrial apoptotic response of colon carcinoma cells does not require nuclear DNA. Oncogene 23, 7449-7457.

Gradishar, W. J. (2011). The place for eribulin in the treatment of metastatic breast cancer. Curr. Oncol. Rep. $13,11-16$.

Gralla, R. J., Gatzemeier, U., Gebbia, V., Huber, R., O'Brien, M., and Puozzo, C. (2007). Oral vinorelbine in the treatment of non-small cell lung cancer: rationale and implications for patient management. Drugs 67, 1403-1410.

Green, D. R., Ferguson, T., Zitvogel, L., and Kroemer, G. (2009). Immunogenic and tolerogenic cell death. Nat. Rev. Immunol. 9, 353-363.

Guchelaar, H. J., Vermes, I., Koopmans, R. P., Reutelingsperger, C. P., and Haanen, C. (1998). Apoptosis- and necrosisinducing potential of cladribine, cytarabine, cisplatin, and 5-fluorouracil in vitro: a quantitative pharmacodynamic model. Cancer Chemother. Pharmacol. 42, 77-83.

Guerrouahen, B. S., Futami, M., Vaklavas, C., Kanerva, J., Whichard, Z. L., Nwawka, K., Blanchard, E. G., Lee, F. Y., Robinson, L. J.,Arceci, R., Kornblau, S. M., Wieder, E., Cayre, Y. E., and Corey, S. J. (2010). Dasatinib inhibits the growth of molecularly heterogeneous myeloid leukemias. Clin. Cancer Res. 16, 1149-1158.

Gumireddy, K., Reddy, M. V., Cosenza, S. C., Boominathan, R., Baker, S. J., Papathi, N., Jiang, J., Holland, J., and Reddy, E. P. (2005). ON01910, a non-ATP-competitive small molecule inhibitor of Plk1, is a potent anticancer agent. Cancer Cell 7, 275-286.

Han, W., Li, L., Qiu, S., Lu, Q., Pan, Q., Gu, Y., Luo, J., and Hu, X. (2007). Shikonin circumvents cancer drug resistance by induction of a necroptotic death. Mol. Cancer Ther. 6, 1641-1649.

Harley, M. E., Allan, L. A., Sanderson, H. S., and Clarke, P. R. (2010). Phosphorylation of Mcl-1 by CDK1-cyclin B1 initiates its Cdc20- dependent destruction during mitotic arrest. EMBO J. 29, 2407-2420.

Harrington, E. A., Bebbington, D., Moore, J., Rasmussen, R. K., Ajose-Adeogun, A. O., Nakayama, T., Graham, J. A., Demur, C., Hercend, T., Diu-Hercend, A., Su, M., Golec, J. M., and Miller, K. M. (2004). VX-680, a potent and selective small-molecule inhibitor of the Aurora kinases, suppresses tumor growth in vivo. Nat. Med. 10, 262-267.

He, S., Wang, L., Miao, L., Wang, T., Du, F., Zhao, L., and Wang, X. (2009). Receptor interacting protein kinase-3 determines cellular necrotic response to TNF-alpha. Cell 137, 1100-1111.

Hewitt, L., Tighe, A., Santaguida, S., White, A. M., Jones, C. D., Musacchio, A., Green, S., and Taylor, S. S. (2010). Sustained Mps1 activity is required in mitosis to recruit O-Mad2 to the Mad1-C-Mad2 core complex. J. Cell Biol. 190, 25-34.

Hirt, U. A., and Leist, M. (2003). Rapid, noninflammatory and PS-dependent phagocytic clearance of necrotic cells. Cell Death Differ. 10, 1156-1164.

Hitomi, J., Christofferson, D. E., Ng, A., Yao, J., Degterev, A., Xavier, R. J., and Yuan, J. (2008). Identification of a molecular signaling network that regulates a cellular necrotic cell death pathway. Cell 135, 1311-1323.

Hoar, K., Chakravarty, A., Rabino, C., Wysong, D., Bowman, D., Roy, N., and Ecsedy, J. A. (2007). MLN8054, a small-molecule inhibitor of Aurora A, causes spindle pole and chromosome congression defects leading to aneuploidy. Mol. Cell. Biol. 27, 4513-4525.

Hoffmann, J., Vitale, I., Buchmann, B., Galluzzi, L., Schwede, W., Senovilla, L., Skuballa, W., Vivet, S., Lichtner, R. B., Vicencio, J. M., Panaretakis, T., Siemeister, G., Lage, H., Nanty, L., Hammer, S., Mittelstaedt, K., Winsel, S., Eschenbrenner, J., Castedo, M., Demarche, C., Klar, U., and Kroemer, G. (2008). Improved cellular pharmacokinetics and pharmacodynamics underlie the wide anticancer activity of sagopilone. Cancer Res. 68, 5301-5308.

Hortelano, S., and Bosca, L. (1997). 6-Mercaptopurine decreases the $\mathrm{Bcl}-2 / \mathrm{Bax}$ ratio and induces apoptosis in activated splenic B lymphocytes. Mol. Pharmacol. 51, 414-421.

Howell, A. (2005). Adjuvant aromatase inhibitors for breast cancer. Lancet 366, 431-433.

Howell, A., Cuzick, J., Baum, M., Buzdar, A., Dowsett, M., Forbes, J. F., HoctinBoes, G., Houghton, J., Locker, G. Y., and Tobias, J. S. (2005). Results of the ATAC (Arimidex, Tamoxifen, Alone or in Combination) trial after completion of 5 years' adjuvant treatment for breast cancer. Lancet 365, 60-62.
Hoy, S. M., and Wagstaff, A. J. (2006). Panitumumab: in the treatment of metastatic colorectal cancer. Drugs 66, 2005-2014; discussion 2015-2006.

$\mathrm{Hu}, \mathrm{X}$., and Xuan, Y. (2008). Bypassing cancer drug resistance by activating multiple death pathways - a proposal from the study of circumventing cancer drug resistance by induction of necroptosis. Cancer Lett. 259, 127-137.

Huang, S., Shu, L., Easton, J., Harwood, F. C., Germain, G. S., Ichijo, H., and Houghton, P. J. (2004). Inhibition of mammalian target of rapamycin activates apoptosis signal-regulating kinase 1 signaling by suppressing protein phosphatase 5 activity. J. Biol. Chem. 279, 36490-36496.

Huang, W. Y., Yang, P. M., Chang, Y. F., Marquez, V. E., and Chen, C. C. (2011). Methotrexate induces apoptosis through p53/p21-dependent pathway and increases E-cadherin expression through downregulation of HDAC/EZH2. Biochem. Pharmacol. $81,510-517$.

Huang, Y. F., Chang, M. D., and Shieh, S.Y (2009).TTK/hMps1 mediates the p53dependent postmitotic checkpoint by phosphorylating p53 at Thr18. Mol. Cell. Biol. 29, 2935-2944.

Huck, J. J., Zhang, M., McDonald, A., Bowman, D., Hoar, K. M., Stringer, B. Ecsedy, J., Manfredi, M. G., and Hyer, M. L. (2010). MLN8054, an inhibitor of Aurora A kinase, induces senescence in human tumor cells both in vitro and in vivo. Mol. Cancer Res. 8, 373-384.

Hudes, G., Carducci, M., Tomczak, P., Dutcher, J., Figlin, R., Kapoor, A., Staroslawska, E., Sosman, J., McDermott, D., Bodrogi, I., Kovacevic, Z., Lesovoy, V., Schmidt-Wolf, I. G. Barbarash, O., Gokmen, E., O'Toole, T., Lustgarten, S., Moore, L., Motzer, R. J. and Global ARCC Trial. (2007). Temsirolimus, interferon alfa, or both for advanced renal-cell carcinoma. $N$. Engl. J. Med. 356, 2271-2281.

Hudis, C. A. (2007). Trastuzumab-mechanism of action and use in clinical practice. N. Engl. J. Med. 357, 39-51.

Huszar, D., Theoclitou, M. E., Skolnik, J., and Herbst, R. (2009). Kinesin motor proteins as targets for cancer therapy. Cancer Metastasis Rev. 28, 197-208.

Hwang, P. M., Bunz, F., Yu, J., Rago, C. Chan, T. A., Murphy, M. P., Kelso, G. F., Smith, R. A., Kinzler, K. W., and Vogelstein, B. (2001). Ferredoxin reductase affects p53-dependent, 5-fluorouracil-induced apoptosis in colorectal cancer cells. Nat. Med. 7, 1111-1117.

Iacobini, M., Menichelli, A., Palumbo, G., Multari, G., Werner, B., and Del Principe, D. (2001). Involvement of oxygen radicals in cytarabine-induced apoptosis in human polymorphonuclear cells. Biochem. Pharmacol. 61, 1033-1040.

Jaglowski, S. M., Alinari, L., Lapalombella, R., Muthusamy, N., and Byrd, J. C. (2010). The clinical application of monoclonal antibodies in chronic lymphocytic leukemia. Blood 116, 3705-3714.

Jani, J. P., Arcari, J., Bernardo, V., Bhattacharya, S. K., Briere, D., Cohen, B. D., Coleman, K., Christensen, J. G., Emerson, E. O., Jakowski, A., Hook, K., Los, G., Moyer, J. D., PruimboomBrees, I., Pustilnik, L., Rossi, A. M., Steyn, S. J., Su, C., Tsaparikos, K., Wishka, D., Yoon, K., and Jakubczak, J. L.. (2010). PF-03814735, an orally bioavailable small molecule aurora kinase inhibitor for cancer therapy. Mol. Cancer Ther. 9, 883-894.

Jayadev, S., Hayter, H. L., Andrieu, N., Gamard, C. J., Liu, B., Balu, R., Hayakawa, M., Ito, F., and Hannun, Y. A. (1997). Phospholipase A2 is necessary for tumor necrosis factor alphainduced ceramide generation in L929 cells. J. Biol. Chem. 272, 17196-17203.

Ji, C., Yang, B., Yang, Y. L., He, S. H., Miao, D. S., He, L., and Bi, Z. G. (2010), Exogenous cell-permeable C6 ceramide sensitizes multiple cancer cell lines to Doxorubicin-induced apoptosis by promoting AMPK activation and MTORC1 inhibition. Oncogene 29, 6557-6568.

Joel, S. (1996). The comparative clinical pharmacology of vincristine and vindesine: does vindesine offer any advantage in clinical use? Cancer Treat. Rev. 21, 513-525.

Joza, N., Oudit, G. Y., Brown, D., Benit, P., Kassiri,Z., Vahsen, N., Benoit, L., Patel, M. M., Nowikovsky, K., Vassault, A., Backx, P. H., Wada, T., Kroemer, G., Rustin, P., and Penninger, J.M. (2005). Muscle-specific loss of apoptosisinducing factor leads to mitochondrial dysfunction, skeletal muscle atrophy, and dilated cardiomyopathy. Mol. Cell. Biol. 25, 10261-10272.

Joza, N., Susin, S. A., Daugas, E., Stanford, W. L., Cho, S. K., Li, C. Y., Sasaki, T., Elia, A. J., Cheng, H. Y., Ravagnan, L., Ferri, K. F., Zamzami, N., Wakeham, A., Hakem, R., Yoshida, H., Kong, Y. Y., Mak, T. W., Zúñiga-Pflücker, J. C., Kroemer, G., and Penninger, J. M. (2001). Essential role of the mitochondrial apoptosis-inducing factor in programmed cell death. Nature 410 , 549-554.

Kandioler-Eckersberger, D., Ludwig, C., Rudas, M., Kappel, S., Janschek, E. Wenzel, C., Schlagbauer-Wadl, H., Mittlbock, M., Gnant, M., Steger, G., and Jakesz, R. (2000). TP53 mutation 
and $\mathrm{p} 53$ overexpression for prediction of response to neoadjuvant treatment in breast cancer patients. Clin. Cancer Res. 6, 50-56.

Kanthou, C., and Tozer, G. M. (2007). Tumour targeting by microtubuledepolymerizing vascular disrupting agents. Expert Opin. Ther. Targets 11, 1443-1457.

Karpinich, N. O., Tafani, M., Rothman, R. J., Russo, M.A., and Farber, J. L. (2002). The course of etoposide-induced apoptosis from damage to DNA and $\mathrm{p} 53$ activation to mitochondrial release of cytochrome c. J. Biol. Chem. 277, 16547-16552.

Kelly, J. D., Williamson, K. E., Weir, H. P., McManus, D. T., Hamilton, P. W., Keane, P.F., and Johnston, S.R. (2000). Induction of apoptosis by mitomycin$C$ in an ex vivo model of bladder cancer. BJU Int. 85, 911-917.

Kepp, O., Galluzzi, L., Zitvogel, L., and Kroemer, G. (2010). Pyroptosis - a cell death modality of its kind? Eur. J. Immunol. 40, 627-630.

Kerr, J. F. (1965). A histochemical study of hypertrophy and ischaemic injury of rat liver with special reference to changes in lysosomes. J. Pathol. Bacteriol. 90, 419-435.

Kerr, J. F., Wyllie, A. H., and Currie, A. R. (1972). Apoptosis: a basic biological phenomenon with wide-ranging implications in tissue kinetics. $\mathrm{Br}$. J. Cancer 26, 239-257.

Ketley, N. J., Allen, P. D., Kelsey, S. M., and Newland, A. C. (1997). Modulation of idarubicin-induced apoptosis in human acute myeloid leukemia blasts by all-trans retinoic acid, 1,25(OH)2 vitamin D3, and granulocyte-macrophage colony-stimulating factor. Blood 90, 4578-4587.

Kim, Y. S., Morgan, M. J., Choksi, S., and Liu, Z. G. (2007). TNF-induced activation of the Nox1 NADPH oxidase and its role in the induction of necrotic cell death. Mol. Cell 26, 675-687.

Kitzen, J. J., de Jonge, M. J., and Verweij, J. (2010). Aurora kinase inhibitors. Crit. Rev. Oncol. Hematol. 73, 99-110.

Koyama, M., Izutani, Y., Goda, A. E., Matsui, T.A., Horinaka, M., Tomosugi, M., Fujiwara, J., Nakamura, Y., Wakada, M., Yogosawa, S., Sowa, Y., and Sakai, T. (2010). Histone deacetylase inhibitors and 15-deoxy-Delta12,14-prostaglandin 22 synergistically induce apoptosis. Clin. Cancer Res. 16, 2320-2332.

Kroemer, G., Galluzzi, L., and Brenner, C. (2007). Mitochondrial membrane permeabilization in cell death. Physiol. Rev. 87, 99-163.

Kroemer, G., Galluzzi, L., Vandenabeele, P., Abrams, J., Alnemri, E. S., Baehrecke, E. H., Blagosklonny, M. V., El-Deiry, W. S., Golstein, P., Green,
D. R., Hengartner, M., Knight, R. A., Kumar, S., Lipton, S. A., Malorni, W., Nuñez, G., Peter, M. E., Tschopp, J., Yuan, J., Piacentini, M., Zhivotovsky, B., Melino, G., and Nomenclature Committee on Cell Death. (2009). Classification of cell death: recommendations of the Nomenclature Committee on Cell Death 2009. Cell Death Differ. 16, 3-11.

Kroemer, G., and Levine, B. (2008). Autophagic cell death: the story of a misnomer. Nat. Rev. Mol. Cell Biol. 9, 1004-1010.

Krumschnabel, G., Sohm, B., Bock, F., Manzl, C., and Villunger, A. (2009). The enigma of caspase-2: the laymen's view. Cell Death Differ. 16, 195-207.

Krysko, D. V., Brouckaert, G., Kalai, M., Vandenabeele, P., and D'Herde, K. (2003). Mechanisms of internalization of apoptotic and necrotic L929 cells bya macrophage cell line studied by electron microscopy. J. Morphol. 258, 336-345.

Krysko, D. V., Denecker, G., Festjens, N., Gabriels, S., Parthoens, E., D’Herde, K., and Vandenabeele, P. (2006). Macrophages use different internalization mechanisms to clear apoptotic and necrotic cells. Cell Death Differ. 13, 2011-2022.

Krysko, O., De Ridder, L., and Cornelissen, M. (2004). Phosphatidylserine exposure during early primary necrosis (oncosis) in JB6 cells as evidenced by immunogold labeling technique. Apoptosis 9, 495-500.

Kwiatkowski, N., Jelluma, N. Filippakopoulos, P., Soundararajan, M., Manak, M. S., Kwon, M., Choi, H. G., Sim, T., Deveraux, Q. L., Rottmann, S., Pellman, D., Shah, J. V., Kops, G. J., Knapp, S., and Gray, N. S. (2010). Small-molecule kinase inhibitors provide insight into Mps1 cell cycle function. Nat. Chem. Biol. 6, 359-368.

Lad, L., Luo, L., Carson, J. D., Wood, K. W., Hartman, J. J., Copeland, R. A., and Sakowicz, R. (2008). Mechanism of inhibition of human KSP by ispinesib. Biochemistry 47, 3576-3585.

Lanza, L., Scudeletti, M., Puppo, F., Bosco, O., Peirano, L., Filaci, G., Fecarotta, E., Vidali, G., and Indiveri, F. (1996). Prednisone increases apoptosis in in vitro activated human peripheral blood T lymphocytes. Clin. Exp. Immunol. 103, 482-490.

Lauber, K., Bohn, E., Krober, S. M., Xiao, Y. J., Blumenthal, S. G., Lindemann, R. K., Marini, P., Wiedig, C., Zobywalski, A., Baksh, S., Xu, Y., Autenrieth, I. B., Schulze-Osthoff, K., Belka, C., Stuhler, G., and Wesselborg, S. (2003). Apoptotic cells induce migration of phagocytes via caspase-3-mediated release of a lipid attraction signal. Cell 113, 717-730.
Laurent, G., and Jaffrezou, J. P. (2001). Signaling pathways activated by daunorubicin. Blood 98, 913-924.

Law, C. L., Gordon, K. A., Collier, J., Klussman, K., McEarchern, J. A., Cerveny, C. G., Mixan, B. J., Lee, W. P., Lin, Z., Valdez, P., Wahl, A. F., and Grewal, I. S. (2005). Preclinical antilymphoma activity of a humanized anti-CD40 monoclonal antibody, SGN-40. Cancer Res. 65, 8331-8338.

Lee, J. J., and Swain, S. M. (2008). The epothilones: translating from the laboratory to the clinic. Clin. Cancer Res. 14, 1618-1624.

Lens, S. M., Voest, E. E., and Medema, R. H. (2010). Shared and separate functions of polo-like kinases and aurora kinases in cancer. Nat. Rev. Cancer 10, 825-841.

Lettre, G., and Hengartner, M. O. (2006). Developmental apoptosis in C. elegans: a complex CEDnario. Nat. Rev. Mol. Cell Biol. 7, 97-108.

Li, L., Tanaka, T., Yukawa, K., Akira, S. and Umesaki, N. (2009). Irinotecaninduced ovarian follicular apoptosis is attenuated by deleting the kinase domain of death-associated protein kinase. Int. J. Oncol. 34, 905-914.

Ling, Y. H., Lin, R., and Perez-Soler, R. (2008). Erlotinib induces mitochondrial-mediated apoptosis in human H3255 non-small-cell lung cancer cells with epidermal growth factor receptorL858R mutation through mitochondrial oxidative phosphorylation-dependent activation of BAX and BAK. Mol. Pharmacol. 74, 793-806.

Lisztwan, J., Pornon, A., Chen, B., Chen, S., and Evans, D. B. (2008). The aromatase inhibitor letrozole and inhibitors of insulin-like growth factor I receptor synergistically induce apoptosis in in vitro models of estrogen-dependent breast cancer. Breast Cancer Res. 10 , R56.

Llobet, D., Eritja, N., Yeramian, A., Pallares, J., Sorolla, A., Domingo, M., Santacana, M., Gonzalez-Tallada, F. J., Matias-Guiu, X., and Dolcet, X. (2010). The multikinase inhibitor Sorafenib induces apoptosis and sensitises endometrial cancer cells to TRAIL by different mechanisms. Eur. J. Cancer 46, 836-850.

Lo, Y. L., Ho, C. T., and Tsai, F. L. (2008) Inhibit multidrug resistance and induce apoptosis by using glycocholic acid and epirubicin. Eur. J. Pharm. Sci. 35, 52-67.

Lockshin, R. A., and Williams, C. M. (1964). Programmed cell death - II. Endocrine potentiation of the breakdown of the intersegmental muscles of silkmoths. J. Insect Physiol. 10, 643-649.
Lou, P. J., Jager, H. R., Jones, L., Theodossy, T., Bown, S. G., and Hopper, C. (2004). Interstitial photodynamic therapy as salvage treatment for recurrent head and neck cancer. Br. J. Cancer 91 , 441-446.

Ma, C. X., Janetka, J. W., and PiwnicaWorms, H. (2011). Death by releasing the breaks: CHK1 inhibitors as cancer therapeutics. Trends. Mol. Med. 17, 88-96.

Mahalingam, D., Medina, E. C., Esquivel, J. A. II, Espitia, C. M., Smith, S., Oberheu, K., Swords, R., Kelly, K. R., Mita, M. M., Mita, A. C., Carew, J. S., Giles, F. J., and Nawrocki, S. T. (2010). Vorinostat enhances the activity of temsirolimus in renal cell carcinoma through suppression of survivin levels. Clin. Cancer Res. 16, 141-153.

Majsterek, I., Gloc, E., Blasiak, J., and Reiter, R. J. (2005). A comparison of the action of amifostine and melatonin on DNA-damaging effects and apoptosis induced by idarubicin in normal and cancer cells. J. Pineal Res. 38, 254-263.

Marchi, E., Paoluzzi, L., Scotto, L., Seshan, V. E., Zain, J. M., Zinzani, P. L., and O'Connor, O.A. (2010). Pralatrexate is synergistic with the proteasome inhibitor bortezomib in in vitro and in vivo models of T-cell lymphoid malignancies. Clin. Cancer Res. 16, 3648-3658.

Marignani, M., Angeletti, S., and delle Fave, G. (2009). Monoclonal antibody therapy and non-Hodgkin's lymphoma. N. Engl. J. Med.360, 192-193; author reply 193.

Marneros, A. G., Grossman, M. E., Silvers, D. N., Husain, S., Nuovo, G. J., MacGregor-Cortelli, B., Neylon, E., Patterson, M., O'Connor, O. A., and Zain, J. M. (2009). Pralatrexateinduced tumor cell apoptosis in the epidermis of a patient with HTLV-1 adult T-cell lymphoma/leukemia causing skin erosions. Blood 113, 6338-6341.

Martin, S. J., Reutelingsperger, C. P., McGahon, A. J., Rader, J.A., van Schie, R. C., LaFace, D. M., and Green, D. R. (1995). Early redistribution of plasma membrane phosphatidylserine is a general feature of apoptosis regardless of the initiating stimulus: inhibition by overexpression of Bcl-2 and Abl. J. Exp. Med. 182, 1545-1556.

McLaughlin, J., Markovtsov, V., Li, H., Wong, S., Gelman, M., Zhu, Y., Franci, C., Lang, D. W., Pali, E., Lasaga, J., Lasaga J., Low. C., Zhao, F., Chang, B., Gururaja, T. L., Xu, W., Baluom, M., Sweeny, D., Carroll, D., Sran, A., Thota, S., Parmer, M. Romane, A., Clemens, G., Grossbard, E., Qu, K., Jenkins, Y., Kinoshita, T., Taylor, V., Holland, S. J., Argade, A., Singh, R., Pine, P., Payan, D. 
G., Hitoshi, Y. (2009). Preclinical characterization of Aurora kinase inhibitor R763/AS703569 identified through an image-based phenotypic screen. J. Cancer Res. Clin. Oncol. 136, 99-113.

Metzger-Filho, O., Moulin, C., de Azambuja, E., and Ahmad, A. (2009). Larotaxel: broadening the road with new taxanes. Expert Opin. Investig. Drugs 18, 1183-1189.

Mi, J., Bolesta, E., Brautigan, D. L., and Larner, J. M. (2009). PP2A regulates ionizing radiation-induced apoptosis through Ser46 phosphorylation of p53. Mol. Cancer Ther. 8, 135-140.

Miele, E., Spinelli, G. P., Tomao, F., and Tomao, S. (2009). Albumin-bound formulation of paclitaxel (Abraxane ABI-007) in the treatment of breast cancer. Int. J. Nanomed. 4, 99-105.

Mitsiades, N., Mitsiades, C. S., Poulaki, V., Chauhan, D., Richardson, P. G., Hideshima, T., Munshi, N. C., Treon, S. P., and Anderson, K. C. (2002). Apoptotic signaling induced by immunomodulatory thalidomide analogs in human multiple myeloma cells: therapeutic implications. Blood 99, 4525-4530.

Mohsin, S. K., Weiss, H. L., Gutierrez, M. C., Chamness, G. C., Schiff, R., Digiovanna, M. P., Wang, C. X., Hilsenbeck, S. G., Osborne, C. K., Allred, D. C., Elledge, R., and Chang, J.C. (2005). Neoadjuvant trastuzumab induces apoptosis in primary breast cancers. J. Clin. Oncol. 23, 2460-2468.

Mok, T. S., Wu, Y. L., Thongprasert, S., Yang, C. H., Chu, D. T., Saijo, N., Sunpaweravong, P., Han, B., Margono, B., Ichinose, Y., Nishiwaki, Y., Ohe, Y., Yang, J. J., Chewaskulyong, B., Jiang, H., Duffield, E. L., Watkins, C. L., Armour, A. A., and Fukuoka, M. (2009). Gefitinib or carboplatin-paclitaxel in pulmonary adenocarcinoma. N. Engl. J. Med. 361, 947-957.

Mooney, C. J., Nagaiah, G., Fu, P., Wasman, J. K., Cooney, M. M., Savvides, P. S., Bokar, J. A., Dowlati, A., Wang, D., Agarwala, S. S., Flick, S. M., Hartman, P H., Ortiz, J. D., Lavertu, P. N., and Remick, S. C. (2009). A phase II trial of fosbretabulin in advanced anaplastic thyroid carcinoma and correlation of baseline serum-soluble intracellular adhesion molecule-1 with outcome. Thyroid 19, 233-240.

Moore, C. M., Pendse, D., and Emberton, M. (2009). Photodynamic therapy for prostate cancer--a review of current status and future promise. Nat. Clin. Pract. Urol. 6, 18-30.

Mori-Abe, A., Tsutsumi, S., Takahashi, K., Toya, M., Yoshida, M., Du, B., Kawagoe, J., Nakahara, K., Takahashi, T., Ohmichi, M., and Kurachi, H. (2003).Estrogen and raloxifene induce apoptosis by activating p38 mitogenactivated protein kinase cascade in synthetic vascular smooth muscle cells. J. Endocrinol. 178, 417-426.

Motzer, R. J., Escudier, B., Oudard, S., Hutson, T. E., Porta, C., Bracarda, S., Grunwald, V., Thompson, J.A., Figlin, R. A., Hollaender, N., Urbanowitz, G., Berg, W. J., Kay, A., Lebwohl, D., Ravaud, A., and RECORD-1 Study Group. (2008). Efficacy of everolimus in advanced renal cell carcinoma: a double-blind, randomised, placebocontrolled phase III trial. Lancet 372, 449-456.

Moubarak, R. S., Yuste, V. J., Artus, C., Bouharrour, A., Greer, P. A., Menissier-de Murcia, J., and Susin, S. A. (2007). Sequential activation of poly(ADP-ribose) polymerase 1 , calpains, and Bax is essential in apoptosis-inducing factor-mediated programmed necrosis. Mol. Cell. Biol. $27,4844-4862$.

Musacchio, A., and Salmon, E. D. (2007). The spindle-assembly checkpoint in space and time. Nat. Rev. Mol. Cell Biol. 8, 379-393.

Nakahara, T., Kita, A., Yamanaka, K., Mori, M., Amino, N., Takeuchi, M., Tominaga, F., Kinoyama, I., Matsuhisa, A., Kudou, M., and Sasamata, M. (2011). Broad spectrum and potent antitumor activities of YM155, a novel small-molecule survivin suppressant, in a wide variety of human cancer cell lines and xenograft models. Cancer Sci. 102, 614-621.

Nakashio, A., Fujita, N., Rokudai, S., Sato, S., and Tsuruo, T. (2000). Prevention of phosphatidylinositol 3'-kinase-Akt survival signaling pathway during topotecan-induced apoptosis. Cancer Res. 60, 5303-5309.

Nazarewicz, R. R., Zenebe, W. J., Parihar, A., Larson, S. K., Alidema, E., Choi, J., and Ghafourifar, P. (2007). Tamoxifen induces oxidative stress and mitochondrial apoptosis via stimulating mitochondrial nitric oxide synthase. Cancer Res. 67, 1282-1290.

Niesvizky, R., Ely, S., Mark, T., Aggarwal, S., Gabrilove, J. L., Wright, J. J., ChenKiang, S., and Sparano, J. A. (2011). Phase 2 trial of the histone deacetylase inhibitor romidepsin for the treatment of refractory multiple myeloma. Cancer 117, 336-342.

Nishioka, C., Ikezoe, T., Yang, J., Koeffler, H. P., and Taguchi, H. (2007). Fludarabine induces apoptosis of human T-cell leukemia virus type 1-infected T cells via inhibition of the nuclear factor-kappaB signal pathway. Leukemia 21, 1044-1049.

Niu, G., Sun, X., Cao, Q., Courter, D., Koong, A., Le, Q. T., Gambhir, S.S., and Chen, X. (2010). Cetuximab-based immunotherapy and radioimmunotherapy of head and neck squamous cell carcinoma. Clin. Cancer Res. 16 , 2095-2105.

Nuckel, H., Frey, U. H., Roth, A., Duhrsen, U., and Siffert, W. (2005). Alemtuzumab induces enhanced apoptosis in vitro in B-cells from patients with chronic lymphocytic leukemia by antibody-dependent cellular cytotoxicity. Eur. J. Pharmacol. 514, 217-224.

Nyman, D. W., Campbell, K. J., Hersh, E., Long, K., Richardson, K., Trieu, V., Desai, N., Hawkins, M. J., and Von Hoff, D. D. (2005). Phase I and pharmacokinetics trial of ABI-007, a novel nanoparticle formulation of paclitaxel in patients with advanced nonhematologic malignancies. J. Clin. Oncol. 23, 7785-7793.

Obeid, M., Tesniere, A., Ghiringhelli, F. Fimia, G. M., Apetoh, L., Perfettini, J. L., Castedo, M., Mignot, G., Panaretakis, T., Casares, N., Métivier D., Larochette, N., van Endert, P., Ciccosanti, F., Piacentini, M., Zitvogel, L., and Kroemer, G. (2007) Calreticulin exposure dictates the immunogenicity of cancer cell death. Nat. Med. 13, 54-61.

Obrero, M., Yu, D. V., and Shapiro, D. J. (2002). Estrogen receptor-dependent and estrogen receptor-independent pathways for tamoxifen and 4-hydroxytamoxifen-induced programmed cell death. J. Biol. Chem. 277, 45695-45703.

Olaussen, K. A., Commo, F., Tailler M., Lacroix, L., Vitale, I., Raza, S. Q., Richon, C., Dessen, P., Lazar, V., Soria, J. C., and Kroemer, G. (2009). Synergistic proapoptotic effects of the two tyrosine kinase inhibitors pazopanib and lapatinib on multiple carcinoma cell lines. Oncogene 28, 4249-4260.

O’Reilly, T., Wartmann, M., Brueggen, J., Allegrini, P. R., Floersheimer, A., Maira, M., and McSheehy, P. M. (2008). Pharmacokinetic profile of the microtubule stabilizer patupilone in tumor-bearing rodents and comparison of anti-cancer activity with other MTS in vitro and in vivo. Cancer Chemother. Pharmacol.62, 1045-1054.

Paesler, J., Gehrke, I., Gandhirajan, R. K., Filipovich,A., Hertweck, M., Erdfelder, F., Uhrmacher, S., Poll-Wolbeck, S. J., Hallek, M., and Kreuzer, K. A. (2010). The vascular endothelial growth factor receptor tyrosine kinase inhibitors vatalanib and pazopanib potently induce apoptosis in chronic lymphocytic leukemia cells in vitro and in vivo. Clin. Cancer Res. 16,3390-3398.

Palucka, K. A., Knaust, E., Xu, D., Macnamara, B., Porwit-Macdonald, A., Gruber, A., Peterson, C.,
Bjorkholm, M., and Pisa, P. (1999). Intraclonal heterogeneity in the in vitro daunorubicin-induced apoptosis in acute myeloid leukemia. Leuk. Lymphoma 32, 309-316.

Panaretakis, T., Kepp, O., Brockmeier, U., Tesniere, A., Bjorklund, A. C., Chapman, D. C., Durchschlag, M., Joza, N., Pierron, G., van Endert, P., Yuan, J., Zitvoge, L., Madeo, F., Williams, D. B., and Kroemer, G. (2009). Mechanisms of pre-apoptotic calreticulin exposure in immunogenic cell death. EMBO J. 28, 578-590.

Panda, D., Miller, H. P., Islam, K., and Wilson, L. (1997). Stabilization of microtubule dynamics by estramustine by binding to a novel site in tubulin: a possible mechanistic basis for its antitumor action. Proc. Natl. Acad. Sci. U.S.A. 94, 10560-10564.

Park, I. C., Park, M. J., Hwang, C. S., Rhee, C. H., Whang, D. Y., Jang, J. J., Choe, T. B., Hong, S. I., and Lee, S. H. (2000). Mitomycin C induces apoptosis in a caspases-dependent and Fas/CD95independent manner in human gastric adenocarcinoma cells. Cancer Lett. $158,125-132$.

Peart, M. J., Tainton, K. M., Ruefli, A. A., Dear, A. E., Sedelies, K. A., O’Reilly, L. A., Waterhouse, N. J., Trapani, J. A., and Johnstone, R. W. (2003). Novel mechanisms of apoptosis induced by histone deacetylase inhibitors. Cancer Res. 63, 4460-4471.

Perez, E. A. (2009). Microtubule inhibitors: Differentiating tubulin-inhibiting agents based on mechanisms of action, clinical activity, and resistance. Mol. Cancer Ther. 8, 2086-2095.

Perez Fidalgo, J. A., Roda, D., Rosello, S., Rodriguez-Braun, E., and Cervantes, A. (2009). Aurora kinase inhibitors: a new class of drugs targeting the regulatory mitotic system. Clin. Transl. Oncol. 11, 787-798.

Pette, M., Gold, R., Pette, D. F., Hartung, H. P., and Toyka, K. V. (1995). Mafosfamide induces DNA fragmentation and apoptosis in human T-lymphocytes. A possible mechanism of its immunosuppressive action. Immunopharmacology 30, 59-69.

Pirnia, F., Schneider, E., Betticher, D. C., and Borner, M. M. (2002). Mitomycin Cinduces apoptosis and caspase- 8 and -9 processing through a caspase- 3 and Fas-independent pathway. Cell Death Differ. 9, 905-914.

Puthalakath, H., Huang, D. C., O'Reilly, L. A., King, S. M., and Strasser, A. (1999). The proapoptotic activity of the Bcl-2 family member Bim is regulated by interaction with the dynein motor complex. Mol. Cell 3, 287-296.

Puthalakath, H., Villunger, A., O’Reilly, L. A., Beaumont, J. G., Coultas, L., 
Cheney, R. E., Huang, D. C., and Strasser, A. (2001). Bmf: a proapoptotic BH3-only protein regulated by interaction with the myosin $\mathrm{V}$ actin motor complex, activated by anoikis. Science 293, 1829-1832.

Rigas, A., Dervenis, C., Giannakou, N., Kozoni, V., Shiff, S. J., and Rigas, B. (2002). Selective induction of colon cancer cell apoptosis by 5 -fluorouracil in humans. Cancer Invest. 20, 657-665.

Riggins, R. B., Zwart, A., Nehra, R., and Clarke, R. (2005). The nuclear factor kappa B inhibitor parthenolide restores ICI 182,780 (Faslodex; fulvestrant)-induced apoptosis in antiestrogen-resistant breast cancer cells. Mol. Cancer Ther. 4, 33-41.

Rivera, E., Lee, J., and Davies, A. (2008). Clinical development of ixabepilone and other epothilones in patients with advanced solid tumors. Oncologist 13, 1207-1223.

Rossi, E. A., Goldenberg, D. M., Cardillo, T. M., Stein, R., Wang, Y., and Chang, C. H. (2008). Novel designs of multivalent anti-CD20 humanized antibodies as improved lymphoma therapeutics. Cancer Res. 68, 8384-8392.

Rudolph, D., Steegmaier, M., Hoffmann, M., Grauert, M., Baum, A., Quant, J., Haslinger, C., Garin-Chesa, P., and Adolf, G. R. (2009). BI 6727, a Pololike kinase inhibitor with improved pharmacokinetic profile and broad antitumor activity. Clin. Cancer Res. 15, 3094-3102.

Ryan, B. M., O'Donovan, N., and Duffy, M. J. (2009). Survivin: a new target for anti-cancer therapy. Cancer Treat. Rev. 35, 553-562.

Sakoe, Y., Sakoe, K., Kirito, K., Ozawa, K., and Komatsu, N. (2010). FOXO3A as a key molecule for all-trans retinoic acid-induced granulocytic differentiation and apoptosis in acute promyelocytic leukemia. Blood 115, 3787-3795.

Sampath, D., Discafani, C. M., Loganzo, F., Beyer, C., Liu, H., Tan, X., Musto, S., Annable, T., Gallagher, P., Rios, C., and Greenberger, L. M. (2003). MAC-321, a novel taxane with greater efficacy than paclitaxel and docetaxel in vitro and in vivo. Mol. Cancer Ther. 2, 873-884.

Sanchez-Alcazar, J. A., Bradbury, D. A., Brea-Calvo, G., Navas, P., and Knox, A. J. (2003). Camptothecin-induced apoptosis in non-small cell lung cancer is independent of cyclooxygenase expression. Apoptosis 8, 639-647.

Santaguida, S., Tighe, A., D'Alise, A. M., Taylor, S. S., and Musacchio, A. (2010). Dissecting the role of MPS1 in chromosome biorientation and the spindle checkpoint through the small molecule inhibitor reversine. J. Cell Biol. 190, 73-87.
Sarli, V., and Giannis, A. (2008). Targeting the kinesin spindle protein: basic principles and clinical implications. Clin. Cancer Res. 14, 7583-7587.

Schiavoni, G., Sistigu, A., Valentini, M., Mattei, F., Sestili, P., Spadaro, F., Sanchez, M., Lorenzi, S., D’Urso, M. T., Belardelli, F., Gabriele, L., Proietti, E., and Bracci, L. (2011). Cyclophosphamide synergizes with type I interferons through systemic dendritic cell reactivation and induction of immunogenic tumor apoptosis. Cancer Res. 71, 768-778.

Schiffer, C. A. (2007). BCR-ABL tyrosine kinase inhibitors for chronic myelogenous leukemia. N. Engl. J. Med. 357, 258-265.

Schmidt, M., Budirahardja, Y., Klompmaker, R., and Medema, R. H. (2005).Ablation of the spindle assembly checkpoint by a compound targeting Mps1. EMBO Rep. 6, 866-872.

Schweichel, J. U., and Merker, H. J. (1973). The morphology of various types of cell death in prenatal tissues. Teratology 7, 253-266.

Schwerdt, G., Freudinger, R., Schuster, C., Weber, F., Thews, O., and Gekle, M. (2005). Cisplatin-induced apoptosis is enhanced by hypoxia and by inhibition of mitochondria in renal collecting duct cells. Toxicol. Sci. 85, 735-742. Shan, D., Gopal, A. K., and Press, O. W. (2001). Synergistic effects of the fenretinide (4-HPR) and anti-CD20 monoclonal antibodies on apoptosis induction of malignant human B cells. Clin. Cancer Res. 7, 2490-2495.

Sharma, S., and Lichtenstein, A. (2008). Dexamethasone-induced apoptotic mechanisms in myeloma cells investigated by analysis of mutant glucocorticoid receptors. Blood 112, 1338-1345.

Shi, J., Tricot, G. J., Garg, T. K., Malaviarachchi, P. A., Szmania, S. M., Kellum, R. E., Storrie, B., Mulder, A., Shaughnessy, J. D., Jr., Barlogie, B., and van Rhee, F. (2008). Bortezomib downregulates the cell-surface expression of HLA class I and enhances natural killer cell-mediated lysis of myeloma. Blood 111, 1309-1317.

Shinzawa, K., and Tsujimoto, Y. (2003). PLA2 activity is required for nuclear shrinkage in caspase-independent cell death. J. Cell Biol. 163, 1219-1230.

Smolewski, P. (2008). Terameprocol, a novel site-specific transcription inhibitor with anticancer activity. IDrugs 11, 204-214.

Steegmaier, M., Hoffmann, M., Baum, A., Lenart, P., Petronczki, M., Krssak, M., Gurtler, U., Garin-Chesa, P., Lieb, S., Quant, J., Grauert, M., Adolf, G. R., Kraut, N., Peters, J.M., and Rettig, W. J. (2007). BI 2536, a potent and selective inhibitor of polo-like kinase 1, inhibits tumor growth in vivo. Curr. Biol. 17, 316-322.

Stein, R., Qu, Z., Chen, S., Rosario, A., Shi, V., Hayes, M., Horak, I. D., Hansen, H. J., and Goldenberg, D. M. (2004). Characterization of a new humanized anti-CD20 monoclonal antibody, IMMU-106, and Its use in combination with the humanized anti-CD22 antibody, epratuzumab, for the therapy of non-Hodgkin's lymphoma. Clin. Cancer Res. 10, 2868-2878.

Sun, X., Li, Y., Li, W., Zhang, B., Wang, A. J., Sun, J., Mikule, K., Jiang, Z., and Li, C. J. (2006). Selective induction of necrotic cell death in cancer cells by beta-lapachone through activation of DNA damage response pathway. Cell Cycle 5, 2029-2035.

Talpaz, M., Shah, N. P., Kantarjian, H., Donato, N., Nicoll, J., Paquette, R., Cortes, J., O'Brien, S., Nicaise, C., Bleickardt, E., Blackwood-Chirchir M. A., Iyer, V., Chen, T. T., Huang, F., Decillis, A. P., and Sawyers, C. L. (2006). Dasatinib in imatinib-resistant Philadelphia chromosome-positive leukemias. N. Engl. J. Med. 354 2531-2541.

Temkin, V., Huang, Q., Liu, H., Osada, H. and Pope, R. M. (2006). Inhibition of ADP/ATP exchange in receptor-interacting protein-mediated necrosis. Mol. Cell. Biol. 26, 2215-2225.

Terrano, D. T., Upreti, M., and Chambers, T. C. (2010). Cyclin-dependent kinase 1-mediated Bcl-xL/Bcl-2 phosphorylation acts as a functional link coupling mitotic arrest and apoptosis. Mol. Cell. Biol. 30, 640-656.

Tesniere, A., Schlemmer, F., Boige, V., Kepp, O., Martins, I., Ghiringhelli, F., Aymeric, L., Michaud, M., Apetoh, L., Barault, L., Mendiboure, J.-P., Pignon, V., Jooste, P., van Endert, M., Ducreux, L., Zitvogel, F. P., and Kroemer, G. (2010). Immunogenic death of colon cancer cells treated with oxaliplatin. Oncogene 29, 482-491.

Thiantanawat, A., Long, B. J., and Brodie, A. M. (2003). Signaling pathways of apoptosis activated by aromatase inhibitors and antiestrogens. Cancer Res. 63, 8037-8050.

Thomas, A., Pepper, C., Hoy, T., and Bentley, P. (2000). Bcl-2 and bax expression and chlorambucil-induced apoptosis in the T-cells and leukaemic B-cells of untreated B-cell chronic lymphocytic leukaemia patients. Leuk. Res. 24, 813-821.

Thon, L., Mohlig, H., Mathieu, S., Lange, A., Bulanova, E., Winoto-Morbach, S., Schutze, S., Bulfone-Paus, S., and Adam, D. (2005). Ceramide mediates caspase-independent programmed cell death. FASEB J. 19, 1945-1956.
Tracy, S., Mukohara, T., Hansen, M., Meyerson, M., Johnson, B. E., and Janne, P. A. (2004). Gefitinib induces apoptosis in the EGFRL858R nonsmall-cell lung cancer cell line H3255. Cancer Res. 64, 7241-7244.

Traganos, F., Seiter, K., Feldman, E., Halicka, H. D., and Darzynkiewicz, Z. (1996). Induction of apoptosis by camptothecin and topotecan. Ann. N.Y. Acad. Sci. 803, 101-110.

Twelves, C., Cortes, J., Vahdat, L. T., Wanders, J., Akerele, C., and Kaufman, P.A. (2010). Phase III trials of eribulin mesylate (E7389) in extensively pretreated patients with locally recurrent or metastatic breast cancer. Clin. Breast Cancer 10, 160-163.

Vakifahmetoglu, H., Olsson, M., and Zhivotovsky, B. (2008). Death through a tragedy: mitotic catastrophe. Cell Death Differ. 15, 1153-1162.

Vakifahmetoglu-Norberg, H., and Zhivotovsky, B. (2010). The unpredictable caspase-2: what can it do? Trends Cell Biol. 20, 150-159.

Van Cutsem, E., Kohne, C. H., Hitre, E., Zaluski, J., Chang Chien, C. R., Makhson, A., D'Haens, G., Pinter, T., Lim, R., Bodoky, G., Roh, J. K., Folprecht, G., Ruff, P., Stroh, C., Tejpar, S., Schlichting, M., Nippgen, J., and Rougier, P. (2009). Cetuximab and chemotherapy as initial treatment for metastatic colorectal cancer. N. Engl. J. Med. 360, 1408-1417.

Van Cutsem, E., Peeters, M., Siena, S., Humblet, Y., Hendlisz, A., Neyns, B., Canon, J. L., Van Laethem, J. L., Maurel, J., Richardson, G., Wolf, M., and Amado, R. G. (2007). Open-label phase III trial of panitumumab plus best supportive care compared with best supportive care alone in patients with chemotherapy-refractory metastatic colorectal cancer. J. Clin. Oncol. 25, 1658-1664.

Vandenabeele, P., Galluzzi, L., Vanden Berghe, T., and Kroemer, G. (2010). Molecular mechanisms of necroptosis: an ordered cellular explosion. Nat. Rev. Mol. Cell Biol. 11, 700-714.

VanderPorten, E. C., Taverna, P., Hogan, J. N., Ballinger, M. D., Flanagan, W. M., and Fucini, R. V. (2009). The Aurora kinase inhibitor SNS-314 shows broad therapeutic potential with chemotherapeutics and synergy with microtubule-targeted agents in a colon carcinoma model. Mol. Cancer Ther. 8, 930-939.

Vanlangenakker, N., Vanden Berghe, T., Bogaert, P., Laukens, B., Zobel, K., Deshayes, K., Vucic, D., Fulda, S., Vandenabeele, P., and Bertrand, M. J. (2011). cIAP1 and TAK1 protect cells from TNF-induced necrosis by preventing RIP1/RIP3-dependent 
reactive oxygen species production. Cell Death Differ. 18, 656-665.

Vidot, S., Witham, J., Agarwal, R., Greenhough, S., Bamrah, H. S., Tigyi, G. J., Kaye, S. B., and Richardson, A. (2010). Autotaxin delays apoptosis induced by carboplatin in ovarian cancer cells. Cell. Signal. 22, 926-935.

Vigneri, P., and Wang, J. Y. (2001). Induction of apoptosis in chronic myelogenous leukemia cells through nuclear entrapment of BCR-ABL tyrosine kinase. Nat. Med. 7, 228-234.

Vitale, I., Galluzzi, L., Senovilla, L., Criollo, A., Jemaa, M., Castedo, M., and Kroemer, G. (2011). Illicit survival of cancer cells during polyploidization and depolyploidization. Cell Death Differ. doi: 10.1038/cdd.2010.145

Vitale, I., Galluzzi, L., Vivet, S., Nanty, L., Dessen, P., Senovilla, L., Olaussen, K. A., Lazar, V., Prudhomme, M., Golsteyn, R. M., Castedo, M., and Kroemer, G. (2007). Inhibition of Chk1 kills tetraploid tumor cells through a p53-dependent pathway. PLoS ONE 2, e1337. doi: 10.1371/ journal.pone. 0001337

Vrana, J.A., Wang, Z., Rao, A. S., Tang, L., Chen, J. H., Kramer, L. B., and Grant, S. (1999). Induction of apoptosis and differentiation by fludarabine in human leukemia cells (U937): interactions with the macrocyclic lactone bryostatin 1. Leukemia 13, 1046-1055. Wagner, C. E., Jurutka, P. W., Marshall, P. A., Groy, T. L., van der Vaart, A., Ziller, J. W., Furmick, J. K., Graeber, M. E., Matro, E., Miguel, B. V., Tran, I. T., Kwon, J., Tedeschi, J. N., Moosavi, S., Danishyar, A., Philp, J. S., Khamees, R. O.,Jackson,J.N.,Grupe,D.K., Badshah, S. L., and Hart, J. W. (2009). Modeling, synthesis and biological evaluation of potential retinoid X receptor (RXR) selective agonists: novel analogues of 4-[1-(3,5,5,8,8-pentamethyl-5,6,7,8tetrahydro-2-naphthyl)ethynyl]benzoic acid (bexarotene). J. Med. Chem. 52, 5950-5966.

Wajant, H. (2002). The Fas signaling pathway: more than a paradigm. Science 296, 1635-1636.

Wang, S., Konorev, E. A., Kotamraju, S., Joseph, J., Kalivendi, S., and Kalyanaraman, B. (2004). Doxorubicin induces apoptosis in normal and tumor cells via distinctly different mechanisms intermediacy of $\mathrm{H}(2)$ $\mathrm{O}(2)$ - and p53-dependent pathways. J. Biol. Chem. 279, 25535-25543.

Warrell, R. P. Jr., Frankel, S. R., Miller, W. H., Jr., Scheinberg, D. A., Itri, L. M.,
Hittelman, W. N., Vyas, R., Andreeff, M., Tafuri, A., and Jakubowski, A. (1991). Differentiation therapy of acute promyelocytic leukemia with tretinoin (all-trans-retinoic acid). $N$. Engl. J. Med. 324, 1385-1393.

Watters, D. (1999). Molecular mechanisms of ionizing radiation-induced apoptosis. Immunol. Cell Biol. 77, 263-271.

Wedam, S. B., Low, J. A., Yang, S. X., Chow, C. K., Choyke, P., Danforth, D., Hewitt, S. M., Berman, A., Steinberg, S. M., Liewehr, D. J., Plehn, J., Doshi, A., Thomasson, D., McCarthy, N., Koeppen, H., Sherman, M., Zujewski, J., Camphausen, K., Chen, H., and Swain, S. M. (2006). Antiangiogenic and antitumor effects of bevacizumab in patients with inflammatory and locally advanced breast cancer. $J$. Clin. Oncol. 24, 769-777.

Whittaker, S. J., Demierre, M. F., Kim, E. J., Rook, A. H., Lerner, A., Duvic, M., Scarisbrick, J., Reddy, S., Robak, T., Becker, J. C., Samtsov, A., McCulloch, W., and Kim, Y.H. (2010). Final results from a multicenter, international, pivotal study of romidepsin in refractory cutaneous T-cell lymphoma. J. Clin. Oncol. 28, 4485-4491.

Wilkinson, R. W., Odedra, R., Heaton, S. P., Wedge, S. R., Keen, N. J., Crafter, C., Foster, J. R., Brady, M. C., Bigley, A., Brown, E., Byth, K. F., and Barrass, N. C. (2007). AZD1152, a selective inhibitor of Aurora B kinase, inhibits human tumor xenograft growth by inducing apoptosis. Clin. Cancer Res. 13, 3682-3688.

Wisniewska-Jarosinska, M., Sliwinski, T., Kasznicki, J., Kaczmarczyk, D., Krupa, R., Bloch, K., Drzewoski, J., Chojnacki, J., Blasiak, J., and Morawiec-Sztandera, A. (2011).Cytotoxicity and genotoxicity of capecitabine in head and neck cancer and normal cells. Mol. Biol. Rep. doi: 10.1007/s11033-010-0482-7

Woessner, R., Tunquist, B., Lemieux, C., Chlipala, E., Jackinsky, S., Dewolf, W., Jr., Voegtli, W., Cox, A., Rana, S., Lee, P., and Walker, D. (2009). ARRY-520, a novel KSP inhibitor with potent activity in hematological and taxaneresistant tumor models. Anticancer Res. 29, 4373-4380.

Won, J. S., and Singh, I. (2006). Sphingolipid signaling and redox regulation. Free Radic. Biol. Med. 40, 1875-1888.

Woo, S., Gardner, E. R., Chen, X., Ockers, S. B., Baum, C. E., Sissung, T. M., Price, D. K., Frye, R., Piekarz, R. L., Bates, S.
E., and Figg, W. D. (2009). Population pharmacokinetics of romidepsin in patients with cutaneous T-cell lymphoma and relapsed peripheral T-cell lymphoma. Clin. Cancer Res. 15, 1496-1503.

Wood, K. W., Lad, L., Luo, L., Qian, X., Knight, S. D., Nevins, N., Brejc, K., Sutton, D., Gilmartin, A. G., Chua, P. R., Desai, R., Schauer, S. P., McNulty, D. E., Annan, R. S., Belmont, L. D., Garcia, C., Lee, Y., Diamond, M. A. Faucette, L. F., Giardiniere, M., Zhang, S., Sun, C.M., Vidal, J. D., Lichtsteiner, S., Cornwell, W. D., Greshock, J. D., Wooster, R. F., Finer, J. T., Copeland, R. A., Huang, P. S., Morgans, D. J. Jr., Dhanak, D., Bergnes, G., Sakowicz, R. and Jackson, J.R. (2010). Antitumor activity of an allosteric inhibitor of centromere-associated proteinE. Proc. Natl. Acad. Sci. U.S.A. 107, 5839-5844.

Wu, L., Adams, M., Carter, T., Chen, R., Muller, G., Stirling, D., Schafer, P., and Bartlett, J. B. (2008). lenalidomide enhances natural killer cell and monocyte-mediated antibody-dependent cellular cytotoxicity of rituximab-treated CD20+ tumor cells. Clin. Cancer Res. 14, 4650-4657.

Xin, H., Zhang, C., Herrmann, A., Du, Y., Figlin, R., and Yu, H. (2009). Sunitinib inhibition of Stat3 induces renal cell carcinoma tumor cell apoptosis and reduces immunosuppressive cells. Cancer Res. 69, 2506-2513.

$\mathrm{Xu}, \mathrm{Y}$., and Villalona-Calero, M. A. (2002). Irinotecan: mechanisms of tumor resistance and novel strategies for modulating its activity. Ann. Oncol. 13, 1841-1851.

Yamashima, T. (2004). $\mathrm{Ca}^{2+}$-dependent proteases in ischemic neuronal death: a conserved 'calpain-cathepsin cascade' from nematodes to primates. Cell Calcium 36, 285-293.

Yamashima, T., and Oikawa, S. (2009). The role of lysosomal rupture in neuronal death. Prog. Neurobiol. 89, 343-358.

Yamashima, T., Tonchev, A. B., Tsukada, T., Saido, T. C., Imajoh-Ohmi, S., Momoi, T., and Kominami, E. (2003). Sustained calpain activation associated with lysosomal rupture executes necrosis of the postischemic CA1 neurons in primates. Hippocampus 13, 791-800.

Ye, K., Ke, Y., Keshava, N., Shanks, J., Kapp, J.A., Tekmal, R. R., Petros, J., and Joshi, H. C. (1998). Opium alkaloid noscapine is an antitumor agent that arrests metaphase and induces apoptosis in dividing cells. Proc. Natl. Acad. Sci. U.S.A. 95, 1601-1606.

Yu, S. W., Wang, H., Poitras, M. F., Coombs, C., Bowers, W. J., Federoff, H. J., Poirier, G. G., Dawson, T. M., and Dawson, V. L. (2002). Mediation of poly(ADP-ribose) polymerase-1dependent cell death by apoptosisinducing factor. Science 297, 259-263. Zabludoff, S. D., Deng, C., Grondine, M. R., Sheehy, A. M., Ashwell, S., Caleb, B. L., Green, S., Haye, H. R., Horn, C. L., Janetka, J. W., Liu, D., Mouchet, E., Ready, S., Rosenthal, J. L., Queva, C., Schwartz, G. K., Taylor, K. J., Tse, A. N., Walker, G. E., and White, A. M. (2008). AZD7762, a novel checkpoint kinase inhibitor, drives checkpoint abrogation and potentiates DNAtargeted therapies. Mol. Cancer Ther. 7, 2955-2966.

Zermati, Y., Garrido, C., Amsellem, S., Fishelson, S., Bouscary, D., Valensi, F., Varet, B., Solary, E., and Hermine, O. (2001). Caspase activation is required for terminal erythroid differentiation. J. Exp. Med. 193, 247-254.

Zhang, D. W., Shao, J., Lin, J., Zhang, N., Lu, B. J., Lin, S. C., Dong, M. Q., and Han, J. (2009). RIP3, an energy metabolism regulator that switches TNF-induced cell death from apoptosis to necrosis. Science 325, 332-336.

Zong, W. X., Ditsworth, D., Bauer, D. E., Wang, Z. Q., and Thompson, C. B. (2004). Alkylating DNA damage stimulates a regulated form of necrotic cell death. Genes Dev. 18, 1272-1282.

Conflict of Interest Statement: The authors declare that the research was conducted in the absence of any commercial or financial relationships that could be construed as a potential conflict of interest.

Received: 18 Februay 2011; accepted: 21 April 2011; published online: 03 May 2011. Citation: Galluzzi L, Vitale I, Vacchelli E and Kroemer G (2011) Cell death signaling and anticancer therapy. 1:5. Front. Oncol. doi: 10.3389/fonc.2011.00005

This article was submitted to Frontiers in Molecular and Cellular Oncology, a specialty of Frontiers in Oncology.

Copyright $\odot 2011$ Galluzzi, Vitale, Vacchelli and Kroemer. This is an open-access article subject to a non-exclusive license between the authors and Frontiers Media SA, which permits use, distribution and reproduction in other forums, provided the original authors and source are credited and other Frontiers conditions are complied with. 